\title{
Türkiye'de aromaterapinin etkisine yönelik yapılan hemşirelik tezlerinin incelenmesi
}

\section{Investigation of nursing thesis about the effects of aromatherapy made in Turkey}

\author{
Murat ZOR ${ }^{* 1} \square$, Didem şiMŞEK KÜÇÜKKELEPÇE²⿴囗十 Zehra GÖLBAŞI² \\ 'Lokman Hekim Üniversitesi, Eczacılık Fakültesi, Ankara/TÜRKiYE \\ ${ }^{2}$ Lokman Hekim Üniversitesi Sağlık Bilimleri Fakültesi, Ebelik Bölümü, ANKARA
}

\section{Öz}

Amaç: Bu araştırma Türkiye'de aromaterapinin etkisini değerlendirmek üzere yapılmış hemşirelik lisansüstü tez çalışmalarının incelenmesi amacıyla yapılmıştır.

Gereç ve Yöntemler: Bu çalışma doküman analizi yöntemi kullanılarak yapılmıştır. Türkiye Ulusal Tez Veri Tabanı'nda "aromaterapi", "nonfarmakolojik yöntemler" ve "hemşirelik" kelimeleri kullanılarak tarama yapılmıştır. Tarama sonucu 66 teze ulaşılmıştır. Tezlerden ikisi tam erişime açık olmadığı, 13’ü hemşirelik tezi olmadığı ve yedisi aromaterapinin etkisini incelemediği için değerlendirme dışı bırakılmış, böylece çalışma 44 tez üzerinden yürütülmüştür.

Bulgular: Tezlerin 24'ü yüksek lisans ve 20'si doktora tezidir. Tezlerin tamamında aromaterapi olarak esansiyel yağ kullanılmıştır. Aromatik yağlar inhaler olarak ya da masaj yöntemiyle uygulanmıştır. Tezlerin 25'inde aromaterapinin kaygı/ anksiyete/stres üzerindeki, 23 tezde uyku ve 19 tezde ise ağrı üzerindeki etkisi incelenmiştir. Çalışmaların tamamına yakınında kullanılan aromaterapinin incelenen değişken üzerinde etkili olduğu bulunmuştur.

Sonuç: Son on yılda hemşireler tarafından aromaterapinin etkisine yönelik yapılan lisansüstü tez çalışmalarının sayısı artmıştır. Çalışmaların sonuçları aromaterapinin ağrı, kaygı, anksiyete, stres ve uyku gibi değişkenler üzerinde olumlu etkileri olduğunu göstermektedir.

Anahtar kelimeler: Aromaterapi; lisansüstü tezler; hemşirelik 


\begin{abstract}
Aim: This study was conducted to examine the nursing graduate thesis conducted to evaluate the effect of aromatherapy in Turkey.

Material and Methods: This study was conducted using the document analysis method. Aromatherapy, nonpharmacological methods and nursing words are used to reach the related theses at the Database of National Thesis Center of Turkey. As a result of the scanning, 66 theses were reached. Two of the theses were excluded because they were not open to full access, 13 were not nursing theses and seven theses did not examine the effect of aromatherapy, and the study was conducted over 44 theses.
\end{abstract}

Results: 24 of the theses are master's and 20 are doctoral dissertations. Essential oil was used as aromatherapy in all of the theses. Aromatic oils were applied as an inhaler or by massage method. While the effect of aromatherapy on anxiety / stress was examined in 25 theses, the effect on sleep was examined in 23 theses and its effect on pain was examined in 19 theses. It was found that aromatherapy used in almost all of the studies was effective on the variable studied.

Conclusion: In the last decade, the number of postgraduate thesis studies conducted by nurses on the effect of aromatherapy has increased. The results of the studies show that aromatherapy has positive effects on variables such as pain, anxiety, stress and sleep.

Keywords: Aromatherapy; postgraduate theses; nursing

\section{Giriş}

Aromaterapi, tamamlayıcı ve alternatif tedavi yöntemlerinden biri olup bitkilerin çeşitli bölümlerinden (yaprak, çiçek, kabuk, meyve, kök) elde edilen aromatik esansiyel yağların tedavi amaçı kullanımı esasına dayanmaktadır. Yaygın kullanım alanı, kullanım kolaylığı, non invazif olması nedeni ile yaygın olarak kullanılmaktadır. Aromaterapi iyileşmeyi sağlamak için, inhaler ve/veya masaj gibi yöntemler şeklinde kullanılarak bazı hastalıklardan korumada, tedaviye destekleyici, fiziksel ve psikolojik iyilik halini yükseltmede kullanılan bir uygulamadır [1,2]. Aromaterapi, koku aracılığı ile limbik sistem ve hipotalamusa kadar uzanan bağlantılarla doğrudan beyin korteksine ulaşabilmektedir. Kortekse ulaşan koku birey üzerinde ruhsal, fiziksel ve davranışsal etkiler yaratmaktadır [2,3]. Aromatik yağların santral sinir sistemi üzerine oluş̧turduğu etki sonucunda rahatlama, sedasyon ve uyarıcı etkiler oluşmaktadır. Santral sinir sisteminin uyarısı ile beyne ulaşan bilgi akımı sayesinde vücuttaki enerji blokajı kırılmakta ve sonuçta enerji açığa çıkmaktadır. Açığa çıkan enerji akımının ilgili organlara dengeli bir biçimde yayılmasıyla iyileşme süreci desteklenmekte, fiziksel ve ruhsal iyilik hali ortaya çıkmaktadır. Aromaterapi, kadın doğum ve kadın sağlığı, nörolojik hastalıklar, kas-iskelet sistemi hastalıkları, otoimmun hastalıklar, sindirim sistemi hastalıkları, kanser ağrıları ve tedavilerinin yan etkilerini azaltma gibi iyilik halini ve yaşam kalitesini artırmada tercih edilmektedir [4-9]. Literatürde aromaterapinin başlıca olarak; doğum ağrısı $[5,10]$, premenstrual sendrom [11], dismenore [12], bebeklerde koliğin giderilmesinde [13], fizyolojik parametreler [9,14], premenopozal dönem vazomotor yakınmalar [8,15], demans [7], osteoartrit [16,17], fibromiyalji [18] kabızlık [6], hipertansiyon [2,14], ağrı yönetimi $[5,7,18]$, kemoterapiye ve gebeliğe bağlı bulantı ve kusma [19,20], yaşam kalitesini artırmada [7,8,15], uyku kalitesini artırmada [22], stres-anksiyeteyi azaltma veya giderme [3,2325] gibi durumlarda yaygın olarak kullanıldığı görülmektedir. Sonuç olarak aromaterapi uygulamaları hastaların bedensel ve ruhsal sorunları dahil olmak üzere birçok tıbbi problemlerde kullanıldığı söylenebilir. Aromaterapi, bireyin sağlığını korumak, geliştirmek, hastalık anında bakım vermek ve rehabilitasyon sürecinde bireyi desteklemekte önemli sorumlulukları olan hemşirelikte de uzun yıllardır kullanılan bir uygulamadır. Florence Nightingale'in, hasta askerlerin alnını lavanta yağı ile ovduğu belirtilmektedir [26]. Son yıllarda ise geleneksel olarak kullanılan aromaterapinin bireyin sağlık sonuçları üzerindeki etkisini değerlendirmeye yönelik yapılan hemşirelik araştırmalarının sayısının arttığı görülmektedir. Bu çalışma sonuçlarının bir bütün olarak değerlendirilmesi aromaterapinin hemşirelik uygulamalarına entegre edilmesinin yolunu açacak ve uygulama alanı giderek genişleyen geleneksel ve tamamlayıcı tıp uygulamalarına sağlık çalışanlarının dikkatini çekecektir.

\section{Gereç ve Yöntemler}

Bu çalışma Türkiye'de hemşire ve ebeler tarafından aromaterapinin etkisini değerlendirmek üzere yapılmış lisansüstü tez çalışma- 
larının incelenmesi amacıyla doküman analizi yöntemi kullanılarak yapılmıştır. Tezlerin taranması 15-24 Ağustos 2020 tarihleri arasında yapılmış olup, arama motoru olarak Türkiye Ulusal Tez Veri tabanı kullanılmıştır. Taramada yıl sınırlaması yapılmadan tüm lisansüstü tezler taranmıştır. Taramada kullanılan anahtar kelimeler Medical Subject Headings (MESH)'ten seçilmiştir. Kullanılan anahtar kelimeler "aromaterapi", "nonfarmakolojik yöntemler" ve "hemşirelik" kelimelerinin kombinasyonlarından oluşmuştur. İlgili anahtar kelimeler ile 66 teze ulaşılmıştır. Bu tezlerden tam metin erişime açık olmayan 2, hemşirelik çalışması olmayan 13 ve aromaterapinin etkisinin incelenmediği (girişimsel olmayan) 7 tez değerlendirme dışı bırakılmıştır. Kalan 44 tez doküman analizi yöntemi ile daha kapsamlı olarak incelenmiştir.

\section{Bulgular}

Bu araştırmada incelenen tezler 2007-2020 tarihleri arasında yürütülmüş olup 20'si yüksek lisans, 24'ü doktora tezidir. Tezlerin tamamında aromaterapi olarak esansiyel yağ kullanılmış olup büyük çoğunluğunda lavanta yağı kullanılmıştır. Aromaterapinin kullanılma yöntemine bakıldığında sıklıkla inhaler ve masaj yönteminin kullanıldığı görülmüştür. Tezlerin 25'inde aromaterapinin kaygı/anksiyete/stres üzerine, 23 tezde uyku ve 19 tezde ise ağrı üzerindeki etkisi incelenmiştir. Tezlerin 16 'sı iç hastalıkları hemşireliği anabilim dalında, 11'i hemşirelik anabilim dalında yürütülmüştür (Tablo 1).

Yapılan yüksek lisans tezleri incelendiğinde sekiz tez çalışmasında aromaterapi uygulamada masaj yönteminin, 13'ünde inhalasyon yönteminin, bir çalışmada inhalasyon ve topikal birlikte ve bir çalışmada ise masaj, inhalasyon ve ayak banyosu şeklinde olduğu ve tamamında lavanta yağının kullanıldığı görülmüştür. Tezlerin tamamına yakınında kontrol grubu kullanılmış olup, yedi çalışmada aromaterapinin uyku üzerindeki etkisi, on çalışmada ağrı üzerindeki etkisi ve dokuz çalışmada da kaygı/stres üzerindeki etkisi incelenmiştir. Aromaterapinin uyku üzerine etkisinin incelendiği çalışmaların çoğunluğunda Pittsburgh Uyku Kalitesi İndeksi (PUKI), ağrı üzerine etkisinin incelendiği çalışmaların çoğunluğunda Visuel Analog Skalası (VAS), kaygı üzerine etkisinin incelendiği çalışmalarda Durumluluk Kaygı Ölçeği (STAI FORM TX-I) kullanılmıştır. Yapılan çaIışmaların sonuçlarına bakıldığında, uygulanan aromaterapinin uyku kalitesini arttırdığı, uygulanan işlemler sırasında, doğumda ağrı töleransını yükselttiği, hissedilen ağrı ve kaygı düzeyini azalttığı görülmüştür. Bunun yanı sıra aromaterapi uygulamasının yaşamsal bulguları olumlu yönde etkilediği ve konfor ve memnuniyet düzeyini arttırdığı bulunmuştur (Tablo 2).

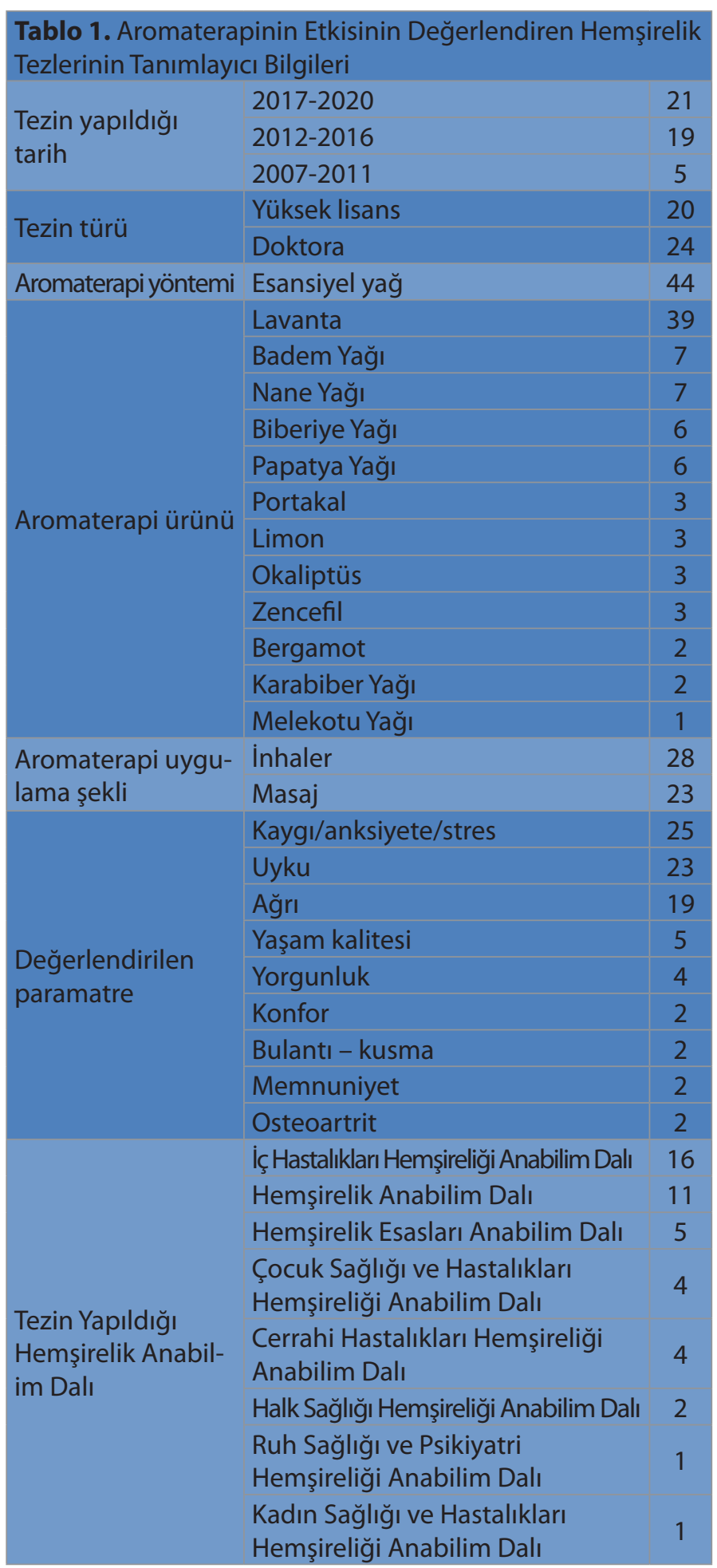

Yapılan doktora tezleri incelendiğinde 13 tez çalışmasında aromaterapi uygulamada masaj yönteminin, 14'ünde inhalasyon yönteminin, dört çalışmada inhalasyon ve masaj yöntemi birlikte kullanılmıştır. Tez çalışmalarının tamamına yakınında lavanta yağı kullanıldığı ve yanı sıra lavanta ile birlikte badem, nane, biberiye, papatya, portakal, limon, okaliptüs, zencefil, bergamot, karabiber, melekotu, ylang-ylang, kakule, katı hindistan cevizi, 
Tablo 2. Aromaterapinin Etkisini Değerlendiren Hemşirelik Yüksek Lisans Tezleri

\begin{tabular}{|c|c|c|c|c|c|}
\hline Yazar/Yılı & Tez Adı & $\begin{array}{l}\text { Çalışmanın } \\
\text { Tipi }\end{array}$ & $\begin{array}{l}\text { Örneklem } \\
\text { Sayısı }\end{array}$ & $\begin{array}{l}\text { Aromatera- } \\
\text { pi yöntemi/ } \\
\text { ürünü/ } \\
\text { uygulama } \\
\text { şekli }\end{array}$ & $\begin{array}{l}\text { Kullanılan } \\
\text { ölçüm aracı }\end{array}$ \\
\hline $\begin{array}{l}\text { Yaman }{ }^{27} \\
\text { S./2011 }\end{array}$ & $\begin{array}{l}\text { Lavanta } \\
\text { yağıyla } \\
\text { uygulanan } \\
\text { sırt masajının } \\
\text { yaşlıların uyku } \\
\text { kalitesine etki- } \\
\text { sinin incelen- } \\
\text { mesi }\end{array}$ & $\begin{array}{l}\text { Ön Test-Son } \\
\text { Test Den- } \\
\text { eme Modeli } \\
\text { Yarı Deney- } \\
\text { sel Çalışma }\end{array}$ & $\begin{array}{l}60 \text { kişi } \\
\text { Masaj } \\
\text { grubu: } 34 \\
\text { Aromatera- } \\
\text { pi + Masajı } \\
\text { grubu: } 34\end{array}$ & $\begin{array}{l}\text { Esansi- } \\
\text { yel Yağ / } \\
\text { Lavanta/ } \\
\text { Masaj }\end{array}$ & $\begin{array}{l}\text { Pittsburg Uyku } \\
\text { Kalitesi İndeksi } \\
\text { (PUKI), Pitts- } \\
\text { burg Uyku Kali- } \\
\text { tesi İndeksinin } \\
3 \text { günlük versi- } \\
\text { yonu (PUKi-3) }\end{array}$ \\
\hline
\end{tabular}

\begin{tabular}{|c|c|c|c|c|c|}
\hline $\begin{array}{l}\text { Karabulut }{ }^{28} \\
\text { H. } / 2014\end{array}$ & $\begin{array}{l}\text { Doğum } \\
\text { eyleminde } \\
\text { aromaterap- } \\
\text { inin etkileri }\end{array}$ & $\begin{array}{l}\text { Randomize } \\
\text { kontrollü } \\
\text { çalışma }\end{array}$ & $\begin{array}{l}60 \text { gebe } \\
\text { Deney } \\
\text { Grubu:30 } \\
\text { Kontrol } \\
\text { Grubu:30 }\end{array}$ & $\begin{array}{l}\text { Esansiyel } \\
\text { Yağ /Lavan- } \\
\text { ta/ Masaj, } \\
\text { inhaler ve } \\
\text { ayak ban- } \\
\text { yosu }\end{array}$ & $\begin{array}{l}\text { Visuel Analog } \\
\text { Skala (VAS), } \\
\text { Durumluluk } \\
\text { Kaygı Ölçeği } \\
\text { (STAI FORM } \\
\text { TX-I) }\end{array}$ \\
\hline
\end{tabular}

Araştırmada her iki grubun PUKi puan ortalamalarının masaj sonrasında anlamlı olarak düşüş gösterdiği saptanmıştır. Grupların masaj sonrası PUKI puan ortalamaları karşılaştırıldığında ise aromaterapi grubundaki düşüşün masaj grubundan daha fazla olduğu ve aradaki farkın istatistiksel olarak anlamlı olduğu belirlenmiştir $(p<0.001)$.

Aromaterapi uygulanan gruptaki kadınlar, kontrol grubundaki kadınlara göre aktif fazda doğum ağrısını daha az algılamıştır. Geçiş fazında, deney grubundaki kadınlar, kontrol grubundaki kadınlara göre doğum ağrısını daha az algıladıkları bulunmuştur. Deney gurubundaki kadınların kontrol grubundaki kadınlara göre latent fazda ve geçiş fazında yaşadıkları kaygı ve anksiyete düzeylerinin daha düşük olduğu saptandı. Deney grubundaki kadınlarda doğum eyleminin ikinci ve üçüncü evrelerinin süreleri kontrol grubuna göre daha kısa sürdüğü gözlenmiştir. Deney grubundaki yenidoğanların birinci dakika APGAR skor ortalaması kontrol grubundakilere göre daha yüksek bulundu.

Müdahale grubundaki bireylerin kontro

Pittsburgh

Uyku Kalitesi

İndeksi (PUKI),

Visüel Analog

Uyku Skalası

halasyon yolu

ile lavanta yağı

Şentürk 29

A. $/ 2015$

uygulamasının

anksiyete

düzeyi ve

uyku kalite-

sine etkisi
34 kişi

Deney

Grubu:17

Kontrol

Grubu:17
Esansiyel

Yağ /Lavanta/ İnhaler

VAS)- Gündüz

Uykululuk

Düzeyi

Hamilton

Anksiyete
Değerlendirme Ölçeği(HAM-A)

Aromaterap-

inin yoğun

bakım üni-

Barış $^{30}$ tesinde çalışan

N./2015 hemşirelerin

stres ve

anksiyeteleri

üzerine etkisi
Kendinden 45 kişi

Kontrollü, Deney

Yarı Deney- Grubu:28

sel Klinik Kontrol

Çalışma Grubu:17
Algılanan Stres Ölçeği,

Durumluk Kaygı Ölçeği, Sürekli Kaygı Ölçeği, Visuel Analog Scale grubundaki bireylere göre öznel uyku kalitesinin daha yüksek olduğu, VAS gündüz uykululuk puan ortalamalarının düştüğü $(p<0.05)$ saptanmıştır. Müdahale grubundaki bireylerin kontrol grubundaki bireylere göre Hamilton Anksiyete Ölçeği tüm alt boyut ve toplam puan ortalamaları arasındaki farkın istatistiksel olarak ileri derecede anlamlı olduğu bulunmuştur $(p<0.001)$.

Araştırmanın sonunda hemşirelere

uygulanan lavantanın stres ve anksiyete düzeyi ile yaşam bulguları üzerine etkisi olmadığı saptanmıştır ( $p>0.05$ ). Ancak kontrol ve deney grubunda yer alan hemşirelerin uygulama öncesine göre uygulama sonrasında durumluk kaygı skorlarında istatistiksel olarak anlamlı olacak şekilde düşüş görülmüştür (deney grubu için $\mathrm{p}<0.001$ ). 


\begin{tabular}{|c|c|c|c|c|c|c|}
\hline $\begin{array}{l}\text { İlter }{ }^{31} \\
\text { M.S./2016 }\end{array}$ & $\begin{array}{l}\text { Onkoloji } \\
\text { hastalarına } \\
\text { port kateteri- } \\
\text { zasyonu işlemi } \\
\text { sırasında } \\
\text { uygulanan } \\
\text { inhaler aro- } \\
\text { materapinin } \\
\text { ağrıya etkisi }\end{array}$ & $\begin{array}{l}\text { Randomize } \\
\text { kontrollü } \\
\text { çalışma }\end{array}$ & $\begin{array}{l}60 \text { kişi } \\
\text { Deney Grubu:30 Kon- } \\
\text { trol Grubu:30 }\end{array}$ & $\begin{array}{l}\text { Esansi- } \\
\text { yel Yağ / } \\
\text { Portakal, } \\
\text { lavanta ve } \\
\text { papatya } \\
\text { yağı, / } \\
\text { İnhaler }\end{array}$ & $\begin{array}{l}\text { Visuel Ana- } \\
\text { log Scale- } \\
\text { VAS }\end{array}$ & $\begin{array}{l}\text { Müdahale grubunun işlem öncesi } \\
6,2 \pm 1,6 \text { olan ağrı puan ortalamasının, } \\
\text { işlem sırasında } 5,0 \pm 1,2 \text { 'ye düştüğü, işlem } \\
\text { sonrasında tekrar } 5,5 \pm 1,2^{\prime} \text { ye yükseldiği, } \\
\text { kontrol grubunun ise; işlem öncesi } \\
6,0 \pm 0,9 \text { olan ağrı puan ortalamasının, } \\
\text { işlem sırasında } 7,4 \pm 1,4^{\prime} \text { e yükseldiği ve } \\
\text { işlem sonrasında } 6,5 \pm 1,6 \text { 'ya düştüğü } \\
\text { belirlenmiştir ( } p<0.05) \text {. }\end{array}$ \\
\hline $\begin{array}{l}\text { Ayik } 32 \\
\text { C./2016 }\end{array}$ & $\begin{array}{l}\text { Ameliyat önce- } \\
\text { si dönemde } \\
\text { aromaterapi } \\
\text { masajının } \\
\text { anksiyete ve } \\
\text { uyku kalite- } \\
\text { sine etkisinin } \\
\text { incelenmesi }\end{array}$ & $\begin{array}{l}\text { Randomize } \\
\text { kontrollü } \\
\text { çalışma }\end{array}$ & $\begin{array}{l}80 \text { kişi } \\
\text { Deney Grubu: } 40 \text { Kon- } \\
\text { trol Grubu: } 40\end{array}$ & $\begin{array}{l}\text { Esansi- } \\
\text { yel Yağ / } \\
\text { Lavanta/ } \\
\text { Masaj }\end{array}$ & $\begin{array}{l}\text { Richard } \\
\text { Campbell } \\
\text { Uyku Ölçeği } \\
\text { (RCUÖ), } \\
\text { Durumluk } \\
\text { Kaygı Ölçeği } \\
\text { (DKÖ) }\end{array}$ & $\begin{array}{l}\text { Çalışma grubu ile kontrol grubu } \\
\text { arasında ameliyat sabahı DKÖ ve RCUÖ } \\
\text { puan ortalaması bakımından istatistiksel } \\
\text { olarak anlamlı bir fark olduğu ( } p<0.05) \\
\text { saptanmıştır. Çalışma grubunda aroma- } \\
\text { terapi masajından sonra ameliyat sabahı } \\
\text { DKÖ puan ortalamasının ameliyat } \\
\text { öncesi akşama göre düştüğü, aradaki } \\
\text { farkın istatistiksel olarak anlamlı olduğu } \\
(p<0.05) \text { saptanmıştır. }\end{array}$ \\
\hline $\begin{array}{l}\text { Gürakan }{ }^{33} \\
\text { G./2016 }\end{array}$ & $\begin{array}{l}\text { Palyatif bakım } \\
\text { alan kanser } \\
\text { hastalarında } \\
\text { aromaterapi } \\
\text { sırt masajının } \\
\text { ağrı şiddeti } \\
\text { ve plazma } \\
\text { beta endorfin } \\
\text { düzeyine etkisi }\end{array}$ & $\begin{array}{l}\text { Deneysel } \\
\text { araştırma }\end{array}$ & $\begin{array}{l}31 \text { kişi } \\
\text { Aromaterapi:11Masaj: } \\
10 \text { Kontrol:10 }\end{array}$ & $\begin{array}{l}\text { Esansi- } \\
\text { yel Yağ / } \\
\text { Lavanta/ } \\
\text { Masaj }\end{array}$ & $\begin{array}{l}\text { Sayısal Ağrı } \\
\text { Skalası, } \\
\text { Ecog Per- } \\
\text { formans } \\
\text { Durumu } \\
\text { Skalası, } \\
\text { Brief Ağrı } \\
\text { Envanteri }\end{array}$ & $\begin{array}{l}\text { Aromaterapi, masaj ve kontrol grubun- } \\
\text { da bulunan hastaların; ikinci, üçüncü } \\
\text { ve dördüncü uygulamadan sonra } \\
\text { ölçülen ağrı şiddeti puanları ve ECOG } \\
\text { performans durumu puanları arasında } \\
\text { istatistiksel olarak anlamlı bir fark } \\
\text { bulunmuştur ( } p<0.05) \text {. Aromaterapi ve } \\
\text { masaj grubundaki hastaların en şiddetli } \\
\text { ağrı, en hafif ağrı ve ortalama ağrı } \\
\text { puanlarında zamanla anlamlı bir azalma } \\
\text { olduğu saptandı (p<0.05). Ayrıca aroma- } \\
\text { terapi ve masaj grubundaki hastaların } \\
\text { plazma-beta endorfin düzeylerinde } \\
\text { ikinci ölçümde anlamlı bir artış olduğu } \\
\text { saptandı ( } p<0.05 \text { ). }\end{array}$ \\
\hline $\begin{array}{l}\text { Dalkıran } \\
\text { S.S/2017 }\end{array}$ & $\begin{array}{l}\text { Preoperatif } \\
\text { dönem- } \\
\text { deki kanser } \\
\text { hastalarında } \\
\text { lavanta yağı } \\
\text { ile yapılan } \\
\text { sırt masajının } \\
\text { uykuya etkisi }\end{array}$ & $\begin{array}{l}\text { Ön test - } \\
\text { son test } \\
\text { deneme } \\
\text { modeli ile } \\
\text { yarı deney- } \\
\text { sel çalışma }\end{array}$ & $\begin{array}{l}80 \text { kişi } \\
\text { Deney Grubu: } 40 \text { Kon- } \\
\text { trol Grubu: } 40\end{array}$ & $\begin{array}{l}\text { Esansi- } \\
\text { yel Yağ / } \\
\text { Lavanta/ } \\
\text { Masaj }\end{array}$ & $\begin{array}{l}\text { Pittsburg } \\
\text { Uyku Kalitesi } \\
\text { İndeksinin } \\
3 \text { günlük } \\
\text { versiyonu } \\
\text { (PUKI-3) }\end{array}$ & $\begin{array}{l}\text { Öntest deney grubunda uyku kalite- } \\
\text { sinin kontrol grubuna göre daha düşük } \\
\text { olduğu saptanmıştır. Uygulanan lavanta } \\
\text { yağı girişimi sonrasında deney grubun- } \\
\text { da uyku kalitesinin önemsenecek } \\
\text { düzeyde arttığı, kontrol grubunda ise } \\
\text { uyku kalitesinin aradan geçen zamanda } \\
\text { azaldığı saptanmıştır. Deney grubunun } \\
\text { uyku kalitesinin başlangıçta kontrol } \\
\text { grubuna göre düşük olmasına rağmen } \\
\text { girişim sonrasında kontrol grubundan } \\
\text { daha iyi bir uyku kalitesine ulaştığı } \\
\text { belirlenmiştir. }\end{array}$ \\
\hline $\begin{array}{l}\text { Gürler }{ }^{35} \\
\text { M./2017 }\end{array}$ & $\begin{array}{l}\text { Menopozal } \\
\text { dönem- } \\
\text { deki kadınlara } \\
\text { uygulanan } \\
\text { aromaterap- } \\
\text { inin uyku ve } \\
\text { yaşam kalite- } \\
\text { sine etkisi }\end{array}$ & $\begin{array}{l}\text { Ön test ve } \\
\text { son test } \\
\text { düzende, } \\
\text { kontrol gru- } \\
\text { plu deney- } \\
\text { sel çalışma }\end{array}$ & $\begin{array}{l}50 \text { kişi } \\
\text { Deney Grubu: } 27 \\
\text { Kontrol Grubu:30 }\end{array}$ & $\begin{array}{l}\text { Esansiyel } \\
\text { Yağ /Lavan- } \\
\text { ta, Limon/ } \\
\text { İnhaler }\end{array}$ & $\begin{array}{l}\text { Pittsburg } \\
\text { Uyku Ka- } \\
\text { litesi İndeksi } \\
\text { (PUKI) ve } \\
\text { Meno- } \\
\text { poza Özgü } \\
\text { Yaşam Ka- } \\
\text { litesi Ölçeği } \\
\text { (MÖYKÖ) }\end{array}$ & $\begin{array}{l}\text { Müdahale grubunun aromaterapi } \\
\text { öncesi PUKI toplam puanı 14.85 } \pm 1.23 \\
\text { iken, kontrol grubunun uygulama } \\
\text { öncesi PUKI toplam puanı } 15.20 \pm 0.92 \\
\text { bulunmuştur. Aromaterapi sonrası } \\
\text { müdahale grubunun PUKI toplam puanı } \\
9.74 \pm 2.12 \text {, kontrol grubunun PUKI } \\
\text { toplam puanı } 14.60 \pm 1.10 \text { olup gruplar } \\
\text { arasında istatistiksel olarak anlamlı bir } \\
\text { fark bulunmuştur }(p<0.001) \text {. }\end{array}$ \\
\hline
\end{tabular}


ZOR ve ark.

Aromaterapinin etkinliği

eylemind-

$/ 2017$

eki ağrı,

konfor ve
Aromaterap-

inin doğum

memnuni-

yet üzerine

etkisi
Ran-

domize

kontrol- 60 gebe

lü, yarı Deney Grubu:30

deneme Kontrol Grubu:30

modeli

çalışma
Visual Analog

Scale (VAS),

Doğum Kon-

foru Ölçeği

(DKÖ),

Esansiyel

Yağ /

Lavanta/

Inhaler

Postpartum

Kendini

Değerlendirme

Ölçeğinin

"Doğum

Deneyiminden Memnuniyet" alt boyutu

Doğumun Latent fazında VAS ortalaması deney grubunda $3,4 \pm 2,1$, kontrol grubunda $6,6 \pm 2,0$, Aktif fazında deney grubunda $6,1 \pm 1,7$, kontrol grubunda $8,7 \pm 1,0$, Geçiş fazında deney grubunda $8,3 \pm 0,9$, kontrol grubunda ise $9,8 \pm 0,5$ olarak belirlenmiş ve gruplar arasındaki farkın tüm fazlarda anlamlı olduğu saptanmıştır $(p=0,000)$. Doğumun Latent fazında DKÖ puan ortalaması deney grubunda $37,1 \pm 4,4$, kontrol grubunda $30,2 \pm 4,4$, Aktif fazında deney grubunda $36,3 \pm 3,2$, kontrol grubunda $25,3 \pm 4,6$, Geçiş fazında deney grubunda $33,6 \pm 3,9$ kontrol grubunda ise $21,1 \pm 4,7$ olarak belirlenmiş ve gruplar arasındaki farkın tüm fazlarda anlamlı olduğu saptanmıştır $(p=0,000)$. Deney grubunun Doğum Deneyiminden Memnuniyet Ölçeği puan ortalamasının 30,03 $\pm 2,53$, kontrol grubunun $27,6 \pm 3,6$ olduğu ve aradaki farkın istatistiksel olarak anlamlı olduğu bulunmuştur $(p=0,000)$.

kontrol gruplu ön testson test yarı deneme modeli çalışma
Aromaterapinin mastektomi öncesi hastaların anksiyeteleri üzerine etkisi
Beyliklioğlu ${ }^{37}$

A./2017

Genç ${ }^{38} \mathrm{H}$

/2017

\section{Lavanta}

yağının benign prostat hiperplazili hastaların ameliyat öncesi yaşam bulguları ve kaygı düzeyine etkisi
Ön testson test kontrol gruplu yarı deneme modeli çalışma
110 kişi

Deney Grubu:55 Kontrol Grubu:55
Deney grubu:40 Kontrol grubu:40

\section{Esansiyel}

Yağ /

Lavanta/

İnhaler
DurumlukSürekli Anksiyete Envanteri'
Deney grubundaki hastaların ön-test durumluk anksiyete puan ortalamasının $43,00 \pm 11,48$, son-test durumluk anksiyete

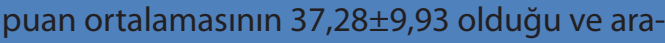
daki farkın istatistiksel olarak anlamlı olduğu saptanmıştır $(p=0,003)$.

Araştırma kapsamında; deney grubunun durumluk kaygı ön test puan ortalaması $65.07 \pm 6.24$ iken aromaterapi sonrası $26.60 \pm 7.47$ 'e düşmüştür. Kontrol grubunda ise durumluk kaygı ön test puan ortalaması $66.29 \pm 4.20$ iken aromaterapi sonrası $63.50 \pm 2.94$ 'e düşmüştür. Deney grubu ile kontrol grubu karşılaştırıldığında fark istatistiksel olarak önemli bulunmuştur. Aromaterapi öncesi ve sonrası yaşam bulgularındaki değişim incelendiğinde ise deney grubundaki bireylerin sistolik kan basıncı ortalaması $127.54 \pm 20.27$ iken, aromaterapi sonrası $124.36 \pm 16.27$ 'ye solunum sayısı ortalaması $21.85 \pm 2.51$ iken, aromaterapi sonrası $20.54 \pm 3.09$ 'a düşmüş, SPO2 ortalaması ise $93.63 \pm 1.89$ iken aromaterapi sonrası $94.09 \pm 1.54$ 'e yükselmiş ve ölçümler arasındaki fark istatistiksel olarak önemli bulunmuştur.

Inhaler

lavantanın Ranhemodiyaliz domize, hastalarında kondamara trollü, ulaşım sırasında oluşan ağrıya etkisi
Müdahale grubunun inhaler lavanta uygulaması öncesi $3.8 \pm 0.3$ olan ağrı puan ortalamasının uygulama sonrası 3.0 0 0.2'ye düştüğü $(p<0.05)$, kontrol grubunun ise ağrı puan ortalamasının $5.4 \pm 0.3^{\prime}$ den, 5.6 \pm 0.6 'ya yükseldiği ve inhaler lavantanın herhangi bir olumsuz etki yaratmadığı saptandı ( $p>0.05$ ). 


\begin{tabular}{|c|c|c|c|c|c|}
\hline $\begin{array}{l}\text { Gülşen }{ }^{40} \\
\text { G./2018 }\end{array}$ & $\begin{array}{l}\text { Üst gastrointes- } \\
\text { tinal endoskopi } \\
\text { işlemi uygulanan } \\
\text { hastalara müzik } \\
\text { eşliğinde uygula- } \\
\text { nan inhaler aro- } \\
\text { materapinin vital } \\
\text { bulgulara etkisi }\end{array}$ & $\begin{array}{l}\text { Ran- } \\
\text { domize, } \\
\text { kontrollü, } \\
\text { deneysel } \\
\text { çalışma }\end{array}$ & $\begin{array}{l}90 \text { kişi } \\
\text { Müzik Grubu:30 } \\
\text { Aromaterapi: } \\
\text { Grubu:30 } \\
\text { Müzik+aromatepi } \\
\text { grubu:30 }\end{array}$ & $\begin{array}{l}\text { Esansiyel } \\
\text { Yağ / } \\
\text { Lavanta, } \\
\text { Papatya, } \\
\text { Neroli/ } \\
\text { Inhaler }\end{array}$ & $\begin{array}{l}\text { Endoskopi } \\
\text { işlemi sonrası } \\
\text { işlem ile } \\
\text { ilgili memniyet } \\
\text { sorularını içeren } \\
\text { form, Vital bulgu } \\
\text { takip formu }\end{array}$ \\
\hline $\begin{array}{l}\text { Kanca }^{41} \\
\text { C./2019 }\end{array}$ & $\begin{array}{l}\text { Diz osteoartriti } \\
\text { olan hastalarda, } \\
\text { ısırgan-zencefil } \\
\text { esansiyel yağlarıyla } \\
\text { yapılan masajın ve } \\
\text { buz uygulamasının } \\
\text { ağrı üzerine } \\
\text { etkinliğinin } \\
\text { değerlendirilmesi }\end{array}$ & $\begin{array}{l}\text { Ön test } \\
\text { son test } \\
\text { tasarımlı } \\
\text { girişimsel, } \\
\text { randomize } \\
\text { kontrollü } \\
\text { çalışma }\end{array}$ & $\begin{array}{l}66 \text { kişi } \\
\text { Aromaterapi } \\
\text { grubu:30 } \\
\text { Buz uygulaması } \\
\text { grubu:22 } \\
\text { Kontrol grubu : } 22\end{array}$ & $\begin{array}{l}\text { Esansiyel } \\
\text { Yağ / } \\
\text { Lavanta, } \\
\text { Isırgan, } \\
\text { zencefil / } \\
\text { Masaj }\end{array}$ & $\begin{array}{l}\text { Sayısal De- } \\
\text { recelendirme } \\
\text { Ölçeği (NRS) } \\
\text { Olgu Rapor } \\
\text { Formu(ORF) }\end{array}$ \\
\hline
\end{tabular}

Hemodiyaliz hastalarında av fistül uygulaması sırasında oluşan ağrıyı gidermede apinin etkisi
90 kişi

İnhaler Aroma-

Randomize terapi grubu:30

kontrollü, Topikal Aroma-

deneysel terapi

çalışma
Esansiyel Sözel Kategori

Yağ / Ölçeği (SKÖ),

Lavanta/ Visuel Analog

İnhaler, Skala(VAS) lavanta aromater-

Araştırmada tüm gruplarda işlem öncesine göre işlem sırasında nabız değerlerinin arttığı, fakat en az artışın grubu ile müzik eşliğinde aromaterapi uygulanan grupta en çok artışın ise kontrol grubunda olduğu görüldü $(p<0.05)$.

Masaj grubunun \%63,6'sının, buz grubunun $\% 36,4$ 'ünün ve kontrol grubunun \%40,9'unun hikayesinde operasyon geçirdiği saptanmıştır. NRS 1.seans değeri masaj grubunda en yüksek değerde iken, NRS 8.seans değeri en düşük masaj grubunda olmuştur. Her üç grupta da NRS 8.seans değerlerinin anlamlı derecede düştüğü görülmekle beraber, en fazla düşüşün masaj grubunda olduğu görülmektedir.

Çalışmaya katılan hemodiyaliz hastalarının uygulama öncesi ağrı puan ortalamaları uygulama grubunda, $57,58 \pm 20,28$, kontrol grubunun $48,53 \pm 20,23$ olduğu, uygulama sonrası uygulama grubunda 19,49 $\pm 15,66$ ve kontrol grubunda $45,33 \pm 25,52$, olduğu belirlendi $(p<0,005)$. Lavanta yağı uygulaması sonrası ağrı puan ortalamaları inhaler lavanta grubunda $22,66 \pm 15,35$, topikal lavanta grubunda $16,33 \pm 15,97$, kontrol grubunda $45,33 \pm 25,52$, plasebo ilk uygulaması sonrası inhaler lavanta grubunda $24 \pm 15,16$, topikal lavanta grubunda $41,16 \pm 16,27$, kontrol grubunda $45,33 \pm 25,52$ olduğu saptandı.

Deney ve kontrol grubunda lavanta yağı inhalasyonunun etkisine bakıldığında yaşam bulgularında aromaterapi sonrası önemli farklılığın olduğu saptanmıştır $(p<0,005)$. Aro-
Lavanta yağının kronik otitis media hastalarının ameliyat öncesi ve kaygı düzeyine etkisi yaşam bulguları
Ön testson test kontrol gruplu yarı Kontrol grubu:44 deneysel çalışma

\section{Hasta Yaşam}

Esansiyel

Yağ / Lavanta/ İnhaler
Bulguları Formu Durumluk Kaygı Ölçeği (DKÖ) materapi öncesi SKB ortalaması 118.30 \pm 12.39 iken aromaterapi sonrası $107.50 \pm 11.44^{\prime} \mathrm{e}$ DKB ortalaması 74.09 \pm 9.96 iken $67.95 \pm 8.79$ 'a, nabız ortalaması $82.55 \pm 9.68$ iken $72.18 \pm 7.46$ 'ya, solunum sayısı ortalaması $20.95 \pm 1.26$ iken 19.32 \pm 1.49 'a düşmüştür. Gruplar arasındaki fark; Nabız, SKB, DKB ve solunum sayısı yönünden istatistiksel olarak anlamlı bulunmuştur $(\mathrm{p}<0,005)$.

İkinci hafta VAS ağrı şiddetinde (VAS2) ve ikinci hafta ve dördüncü hafta ağrı giderme yüzdesinde gruplar arasında anlamlı bir fark saptanmıştır. Aromaterapi grubunda hem ağrı şiddetinde hem de ağrı giderme yüzdesinde anlamlı bir azalma saptanmıştır. Aromaterapi ve kontrol grupları durumluluk-süreklilik kaygı ölçeği puanları açısından kıyaslandığında; her iki grupta da istatistiksel olarak anlamlı fark saptanmıştır. Durumluk sürekli kaygı puanındaki azalma aromaterapi grubunda kontrol grubuna göre daha fazladır. Gruplar uyku kalitesi açısından değerlendirildiğinde ise; hem aromaterapi hem de kontrol grubunda global PUKI uyku kalitesi puanında anlamlı bir azalma olduğu; aromaterapi grubundaki puan azalmasının kontrol grubuna daha fazla olduğu saptanmıştır. 


\begin{tabular}{|c|c|c|c|c|c|}
\hline $\begin{array}{l}z^{45} \\
. / 2019\end{array}$ & $\begin{array}{l}\text { Yaşlılarda } \\
\text { aromaterapi } \\
\text { masajının uyku } \\
\text { kalitesi ve uyku- } \\
\text { luluk düzeyine } \\
\text { etkisi }\end{array}$ & $\begin{array}{l}\text { Ön test- } \\
\text { son test } \\
\text { yarı } \\
\text { deney- } \\
\text { sel } \\
\text { alısma }\end{array}$ & $\begin{array}{l}15 \text { kişi } \\
\text { Aromaterapi } \\
\text { grubu: } 15\end{array}$ & $\begin{array}{l}\text { Esansiyel } \\
\text { Yağ / } \\
\text { Lavanta/ } \\
\text { Masaj }\end{array}$ & $\begin{array}{l}\text { Pittssburg Uyku } \\
\text { Kalitesi Indeksi } \\
\text { (PUKI) } \\
\text { Epworth Uykulu- } \\
\text { luk Skalası }\end{array}$ \\
\hline
\end{tabular}

Arterio-venöz fistül kanülasyonu öncesi uygulanan aromaterapi ve el masajının ağrı ve stres düzeylerine etkisi
Ran- 159 kişi domize Aromaterapi

\section{kon-} deneysel çalışma grubu:53

El masajı

grubu:53

Kontrol gru-

bu:53 trollü,
Aromaterapi masajını uygulamadan önce Pitssburgh uyku kalitesi ölçek değerinin ortalama $15,93+4,11$ olduğu, aromaterapi uyguladıktan sonra yapılan ölçümlerde ise ölçek değerinin ortalama 4,93+2,05 olduğu ve aralarında istatistiksel olarak anlamlı farklılıklar olduğu saptandı $(p=0,001, p<0,05)$. Aromaterapi masajı uygulama öncesinde Epworth uykululuk skalası ölçek değerinin $(12,13+2,44)$, uygulanan aromaterapiden sonra yapılan ölçümlerde $(2,06+1,70)$ daha düşük olduğu ve aralarında istatistiksel olarak anlamlı farklılıklar olduğu saptandı $(p=0,001$, $\mathrm{p}<0,05$ ).

Araştırma sonucunda AVF kanülasyonu öncesi aromaterapi uygulanan hastaların işlemden sonraki ağrı ve düzeylerinin kontrol grubuna göre daha fazla düştüğü, benzer şekilde el masajı uygulanan hastalarda VAS ve HSÖ değerlerinin kontrol grubuna göre daha fazla düştüğü, gruplar arasındaki farkın ileri derecede anlamlı olduğu $(p<0.001)$, seanslar ilerledikçe girişimlerin etkinliğinin arttığı belirlendi. Aromaterapiyle el masajı girişimleri karşılaştırıldığında, AVF kanülasyonunun ağrısını gidermede etkilerinin benzer olduğu, hemodiyaliz fizyolojik stresörleri azaltmada aromaterapinin, psikolojik ve toplam hemohiyaliz stresörlerini azaltmada el masajının daha etkili olduğu ve gruplar arasındaki farkın istatistiksel olarak anlaml olduğu belirlendi. jojoba, yasemin, gül ve menekşe yağının kullanıldığı görülmüştür. Tezlerin tamamına yakınında kontrol grubu kullanılmış olup, iki çalışma tek grup üzerinden yürütülmüştür. Yapılan doktora tezlerine bakıldığında çalışmada aromaterapinin klasik masaj, refleksoloji, müzikterapi, vibrasyon, gevşeme tekniği ve dokunma gibi farklı tamamlayıcı tedavilere birlikte kullanıldığı görülmüştür. Doktora tezleri incelendiğinde, kaygı/anksiyete, ağrı, bulantı-kusma, konfor, kortizol düzeyi, yaşam kalitesi, yorgunluk, bilişsel fonksiyonlar, gündüz uykululuk durumu, uyku kalitesi, bakım yükü, premenstrual semptomlar, yorgunluk, konstipasyon, yaşamsal bulgular, kaşıntı, sigara içme alışkanlıkları ve bebeklerde koliğin üzerindeki etkisi gibi birbirinden farklı pek çok alanda kullanıldığı saptanmıştır. Tezlerde kullanılan ölçüm araçlarına bakıldığında; İnfant Kolik Ölçeği,, Durumluluk Sürekli Kaygı Envanteri, Çok Boyutlu Algılanan Sosyal Destek Ölçeği, Yorgunluk Şiddet Ölçeği, Pittsburg Uyku Kalitesi İndeksi(PUKi), Fibromiyalji Etki Düzeyi ölçeği, Yaşam Kalitesi Ölçeği Rotterdam Semptom Kontrol Listesi, Visuel Analog Scale (VAS), Brazelton Yenidoğan Davranış Değerlendirilme Ölçeği, Günlük Konstipasyon İzlem Formu, Yorgunluk Ciddiyet Skalası, Romatoid Artrit Hastalık Aktivite Değerlendirme formu, WOMAC Diz Osteoartrit Değerlendirme Ölçeği, Alt Bacaklardaki Artroz ve Yaşam Kalitesi Ölçeği, Piper Yorgunluk Ölçeği, Premenstrual Sendrom Ölçeği, Nöropsikiyatrik Envanter (NPE), Cohen-Mansfield Ajitasyon Envanteri (CMAE), Zarit Bakım Verme Yükü Ölçeği (ZYBÖ), The Wes- tern Ontario and McMaster Üniversitesi (WOMAC) Osteoartrit İndeksi, Bulantı Kusma-Öğürmeye İlişskin Hasta Günlüğü Formu, Blessed Oryantasyon Bellek Konsantrasyon Testi, Epworth Uykululuk Ölçeği, Douleur Neuropathique 4 Questions (DN4), Genel Konfor Ölçeği, Hasta ve Hekim Memnuniyet Skalası, Rhodes Bulantı, Kusma ve Öğürme İndeksi, Fagerström Nikotin Bağımlılığı Testi, Ulusal Acil Servisler Kalabalıklaşma Çalışması ölçeği gibi duruma özgü ölçüm araçlarının kullanıldığı görülmektedir. Yapılan çalışmaların sonuçlarına bakıldığında, uygulanan aromaterapinin hissedilen ağrı ve kaygı/anksiyete düzeyini, bulantı- kusma ve öğürmeyi, yorgunluk düzeyi ve şiddetini, ajitasyonu ve bakım verenlerinin bakım yükünü, premenstrual semptomları, konstipasyon şikayetlerini, bebeklerde koliği azalttığı uyku kalitesini, yaşam kalitesini, konfor düzeyini, memnuniyet düzeyini arttırdığı ve fiziksel fonksiyonları, yaşamsal bulguları olumlu yönde etkilediği bulunmuştur (Tablo 3).

\section{Tartışma}

Tamamlayıcı ve alternatif tedavi yöntemlerinin güvenli olduğu inancı ve sağlığa olumlu katkılarının bulunması bu yöntemlerin yaygın olarak kullanılmasını sağlamaktadır. Kullanılan bu yöntemlerden bir de bitkisel ürünlerin kullanımı esasına dayanan aromaterapidir. Aromaterapide kullanılan bitkisel ürünlerin doğal kaynaklı olduğunun bilinmesi, reçete edilmeden rahatlıkla ulaşılabilmesi, ekonomik olması, invazif girişim gerektirmemesi bireyin sağlığı için risk teşkil etmemesi bitkisel 


\begin{tabular}{|c|c|c|c|c|c|c|}
\hline Yazar/Yılı & Tez Adı & $\begin{array}{l}\text { Çalışmanın } \\
\text { Tipi }\end{array}$ & Örneklem Sayısı & $\begin{array}{l}\text { Aromatera- } \\
\text { pi yöntemi/ } \\
\text { ürünü/ } \\
\text { uygulama } \\
\text { şekli }\end{array}$ & $\begin{array}{l}\text { Kullanılan } \\
\text { ölçüm aracı }\end{array}$ & Sonuç \\
\hline $\begin{array}{l}\text { Çetinkaya }{ }^{47} \\
\text { B./2007 }\end{array}$ & $\begin{array}{l}\text { Aromaterapi } \\
\text { Masajının } \\
\text { Bebeklerde } \\
\text { Koliğin } \\
\text { Giderilmesi } \\
\text { Üzerine } \\
\text { Etkisinin } \\
\text { Incelenmesi }\end{array}$ & $\begin{array}{l}\text { Girişim } \\
\text { uygulanma- } \\
\text { yan kontrol } \\
\text { grubu ile } \\
\text { zaman dizisi } \\
\text { modelinde } \\
\text { yarı deney- } \\
\text { sel çalışma }\end{array}$ & $\begin{array}{l}40 \text { kişi } \\
\text { Deney grubu: } 20 \\
\text { Kontrol grubu: } 20\end{array}$ & $\begin{array}{l}\text { Esansi- } \\
\text { yel Yağ / } \\
\text { Lavanta, } \\
\text { Badem } \\
\text { yağı/ Masaj }\end{array}$ & $\begin{array}{l}\text { İnfant Kolik } \\
\text { Ölçeği, } \\
\text { Durumluluk } \\
\text { Sürekli Kaygı } \\
\text { Envanteri } \\
\text { Çok Boyutlu } \\
\text { Algılanan } \\
\text { Sosyal Destek } \\
\text { Ölçeği, }\end{array}$ & $\begin{array}{l}\text { Aromaterapi masajı uygulaması } \\
\text { öncesinde, deney ve kontrol } \\
\text { grubu kolikli bebekler arasında } \\
\text { kolik durumu ve haftalık ağlama } \\
\text { süreleri açıından anlamlı bir } \\
\text { fark saptanmamıştır ( } p>0.05 \text { ). } \\
\text { Ön izlemde, deney ve kontrol } \\
\text { grubu annelerin durumluluk } \\
\text { kaygı durumları arasında istatis- } \\
\text { tiksel olarak anlamlı bir fark } \\
\text { saptanmamıştır ( }>0.05 \text { ). Deney } \\
\text { ve kontrol grubu bebeklerin, } \\
\text { izlemlere göre infant kolik ölçeği } \\
\text { puan ortalamaları ve haftalık } \\
\text { ağlama süreleri incelendiğinde, } \\
\text { iki grup arasında izlemlere göre } \\
\text { anlamlı bir ilişki saptanmıştır } \\
\text { ( } p<0,005 \text { ). }\end{array}$ \\
\hline $\begin{array}{l}\text { Arslan } 48 \\
\text { S./2007 }\end{array}$ & $\begin{array}{l}\text { Dokunma, } \\
\text { Müzikterapi } \\
\text { ve Aroma- } \\
\text { terapinin } \\
\text { Yoğun Bakım } \\
\text { Hastalarının } \\
\text { Fizyolojik } \\
\text { Durumlarına } \\
\text { Etkisi }\end{array}$ & $\begin{array}{l}\text { Randomize } \\
\text { kontrollü } \\
\text { çalışma }\end{array}$ & $\begin{array}{l}72 \text { kişi } \\
\text { Deney Grubu:36 } \\
\text { Kontrol Grubu:36 }\end{array}$ & $\begin{array}{l}\text { Esansiyel } \\
\text { Yağ/Lavan- } \\
\text { ta/İnhaler }\end{array}$ & $\begin{array}{l}\text { Araştırmacılar } \\
\text { tarafından iki } \\
\text { bölümden } \\
\text { oluşturulan } \\
\text { ve ikinci } \\
\text { bölümünde } \\
\text { girişim öncesi } \\
\text { ve sonrası } \\
\text { fizyolojik } \\
\text { ölçümlerinin } \\
\text { kaydedildiği } 3 \\
\text { günlük kayıt } \\
\text { formu }\end{array}$ & 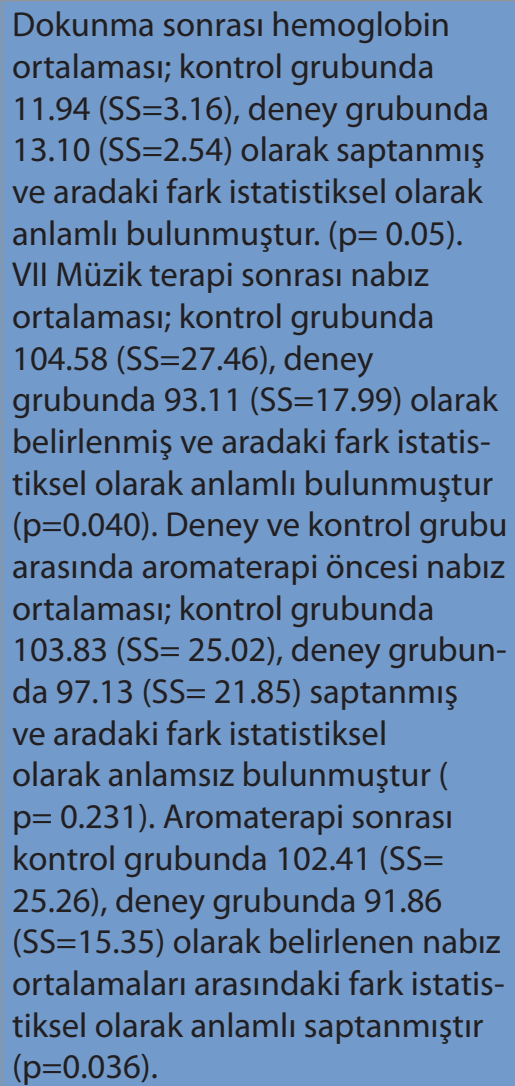 \\
\hline
\end{tabular}


ZOR ve ark.

Aromaterapinin etkinliği

\begin{tabular}{|c|c|c|c|c|c|c|}
\hline $\begin{array}{l}\text { Demirbağ } \\
\text { C. B./2011 }\end{array}$ & $\begin{array}{l}\text { Müzik ve } \\
\text { Aromaterapi } \\
\text { Eşliğinde } \\
\text { Yapılan } \\
\text { Uyku ve } \\
\text { Dokunmanın } \\
\text { Fibromiyalji } \\
\text { Hastalarında } \\
\text { Fibromi- } \\
\text { yaljinin Etki } \\
\text { Düzeyi Ile } \\
\text { Yorgunluk ve } \\
\text { Uyku Kalite- } \\
\text { sine Etkisi }\end{array}$ & $\begin{array}{l}\text { Kontrol gru- } \\
\text { plu öntest- } \\
\text { sontest } \\
\text { deneme } \\
\text { modeli } \\
\text { çalış̧ma }\end{array}$ & $\begin{array}{l}162 \text { kişi } \\
\text { Dokunma+Müzik+Aroma } \\
\text { Grubu: } 54 \\
\text { Uyku+Müzik+Aroma } \\
\text { grubu: } 54 \\
\text { Kontrol Grubu:54 }\end{array}$ & $\begin{array}{l}\text { Esansi- } \\
\text { yel Yağ / } \\
\text { Lavanta, } \\
\text { nane, por- } \\
\text { takal, gül, } \\
\text { papatya, } \\
\text { asya çiçeği, } \\
\text { biberiye, } \\
\text { ateş çiçeği, } \\
\text { Ihlamur } \\
\text { / Masaj, } \\
\text { Inhaler }\end{array}$ & $\begin{array}{l}\text { Yorgun- } \\
\text { luk Şiddet } \\
\text { Ölçeği, } \\
\text { Pittsburg } \\
\text { Uyku Kalitesi } \\
\text { İndeksi Fi- } \\
\text { bromiyalji } \\
\text { Etki Düzeyi } \\
\text { ölçeği }\end{array}$ & $\begin{array}{l}\text { Girişim grubu hastalarında fibro- } \\
\text { miyalji semptom sorgulamass } \\
\text { son-test semptom bulguların } \\
\text { da istatistiksel olarak önemli } \\
\text { fark olması ( } p<0,05 \text { ) girişimin } \\
\text { hastaların semptomlarını azalt- } \\
\text { mada etkili olduğunu göster- } \\
\text { mektedir. Yorgunluk Şiddeti } \\
\text { Ölçeğinin girişim gruplarında } \\
\text { son-test puan ortalamalarında } \\
\text { önemli düşšşün olması (p<0.05), } \\
\text { müdahale sonrası hastaların } \\
\text { yorgunluklarının azaldığını } \\
\text { ifade etmektedir. Fibromi- } \\
\text { yalji Etki Düzeyi Ölçeği ölçeği } \\
\text { puan ortalaması her iki girişim } \\
\text { grubunda sontestte önemli } \\
\text { düşüšsü(p<0,05) hastaların } \\
\text { hastalık durumlarının, hastalığın } \\
\text { gidişinin olumlu yönde } \\
\text { değiştiğini göstermektedir. } \\
\text { Pittsburgh Uyku Kalitesi İndeksi } \\
\text { son-test toplam puanlarının } \\
\text { ortalamalarında her iki girişim } \\
\text { grubunda da önemli farklılık } \\
\text { (p<0.05), olması uyku kalitesi } \\
\text { ve uyku bozukluğunda iyileşme } \\
\text { olduğunu ispatlamaktadır. }\end{array}$ \\
\hline $\begin{array}{l}\text { Ovayolus0 } \\
\text { Ö./2011 }\end{array}$ & $\begin{array}{l}\text { Kemoterapi } \\
\text { Alan Meme } \\
\text { Kanserli } \\
\text { Kadınlara } \\
\text { Uygulanan } \\
\text { Aromaterapin- } \\
\text { in Semptom- } \\
\text { lara ve Yaşam } \\
\text { Kalitesi Etkisi }\end{array}$ & $\begin{array}{l}\text { Randomize } \\
\text { kontrollü } \\
\text { deneysel } \\
\text { çalışma }\end{array}$ & $\begin{array}{l}280 \text { kişi } \\
\text { Aromaterapi masajı } \\
\text { grubu:70 } \\
\text { Aromaterapi inhaler } \\
\text { grubu: } 70 \\
\text { Masaj grubu: } 70 \\
\text { Kontrol Grubu:70 }\end{array}$ & $\begin{array}{l}\text { Esansiyel } \\
\text { Yağ /Lavan- } \\
\text { ta, nane, } \\
\text { biberiye, } \\
\text { papatya, } \\
\text { yasemin, } \\
\text { menekşe, } \\
\text { okalip- } \\
\text { tüs, tatlı } \\
\text { badem/ } \\
\text { Masaj, } \\
\text { İnhaler }\end{array}$ & $\begin{array}{l}\text { Yaşam Ka- } \\
\text { litesi Ölçeği } \\
\text { Rotterdam } \\
\text { Semptom } \\
\text { Kontrol } \\
\text { Listesi }\end{array}$ & $\begin{array}{l}\text { Uygulama öncesi koku ve } \\
\text { aromaterapi masajı grubu- } \\
\text { nun yaşam kalitesi genel to- } \\
\text { plam puanının düşük, kontrol } \\
\text { ve masaj grubunun ise orta } \\
\text { düzeyde olduğu ve tüm hasta } \\
\text { gruplarının hem psikolojik hem } \\
\text { de fiziksel semptomları yoğun } \\
\text { olarak yaşadıkları saptandı. } \\
\text { Uygulama sonrası altıncı ve } 10 . \\
\text { haftalarda; yaşam kalitesi toplam } \\
\text { ve alt boyut puanları kontrol } \\
\text { grubunda düşerken, koku, masaj } \\
\text { ve aromaterapi masajı grubunda } \\
\text { yükseldiği, özellikle aromaterapi } \\
\text { masajı grubunda yer alan has- } \\
\text { talarda bu artışın daha belirgin } \\
\text { olduğu tespit edildi ( } p<0.05 \text { ). } \\
\text { Benzer şekilde Rotterdam semp- } \\
\text { tom kontrol listesi genel toplam, } \\
\text { psikolojik ve fiziksel semptom } \\
\text { alt boyut puan ortalamalarının } \\
\text { kontrol grubunda artarken, } \\
\text { diğer üç grupta özellikle aroma- } \\
\text { terapi masajı grubunda uygulama } \\
\text { öncesine göre anlamlı şekilde } \\
\text { düşsüğü, yani hastaların yaşadığı } \\
\text { semptomların ve şiddetinin } \\
\text { azaldığı belirlendi (p<0.05). }\end{array}$ \\
\hline
\end{tabular}




$\begin{array}{ll} & \text { Hemodiyaliz } \\ \text { Cürcani }{ }^{51} & \text { Hastalarına Uygu- } \\ \text { M./2012 } & \text { lanan Aromater- } \\ & \text { apinin Kaşıntı } \\ & \text { Üzerine Etkisi }\end{array}$

$\begin{array}{ll} & \text { Gevşeme Tekniği, } \\ & \text { Aromaterapi } \\ \text { Taşdemir } & \text { ve Her İki Yön- } \\ \text { N./2012 } & \text { temin Birlikte } \\ & \text { Uygulanmasının } \\ & \text { Ameliyat Sonrası } \\ & \text { Ağrıya Etkisi }\end{array}$

Gevşeme Tekniği, ve Her Iki temin Birlikte Ameliyat Sonras Ağrıya Etkisi
Ön test ve son test kontrol gruplu deneysel çalışma
Esansi-

yel Yağ /

Lavanta, çay ağacı, tatlı badem yağı, Visuel Analog jojoba yağı ve papatya yağı, /

Masajı
Deney ve kontrol grubunda yer alan hastaların kaşıntı skorlarının gruplar arası karşılaştırılmasında; deney grubundaki hastaların kaşıntı skorları son-test puan VI ortalamalarının $(7.20 \pm 3.14)$, kontrol grubundaki hastaların son-test puan ortalamalarına göre $(10.00 \pm 2.47)$ düşük olduğu ve gruplar arasındaki farkın istatistiksel yönden çok öneml olduğu bulundu $(p<0.001)$. Deney ve kontrol grubunda yer alan hastaların laboratuar parametrelerinin gruplar arası karşılaştırmalarında; deney grubundaki hastaların kan üre azotu

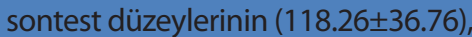
kontrol grubunda bulunan hastaların kan üre azotu sontest düzeylerine

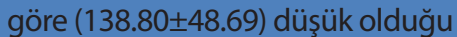
belirlendi ve gruplar arasındaki fark istatistiksel yönden önemli bulundu $(p<0.05)$

Araştırmanın verilere göre, kontrol ve girişim grubu hastalar arasında cerrahi işlem öncesi bireysel özellikleri, ameliyat sonrası ağrı şiddetleri ve yaşam bulguları arasında istatistiksel olarak anlamlı bir fark yoktur. Ameliyat sonrası analjezik gereksinimleri açısından istatistiksel olarak anlamlı fark $(p<0.05)$ olduğu 81 belirlendi. Girişim gruplarındaki hastaların daha düşük analjezik gereksimi olduğu saptandı $(p<0.05)$.

Çalışmada aromaterapinin ilk haftasında sistolik kan basıncı $(p<0.001)$, diastolik kan basıncı $(p<0.001)$, nabız hızı $(p<0.001)$ ve durumluluk kaygı puanının azaldığı $(p<0.001)$, biopac parametrelerinde yalnızca galvanik deri direncinde anlamlı azalma ( $p=0.038)$ sağladığı saptanmıştır.

Araştırmanın birinci aşamasında, yapılan faktör analizi sonrasında, BYDDÖ'nin orjinalinden 5 madde çıkartılmış. Cronbach alfa değeri 0.974 (30 madde) olarak bulunmuş. "Davranış Alt Boyutu" 23 madde, "Destek Alt Boyutu" 7 maddeden oluşmuştur. Tekrar test güvenirliğinde korelasyon katsayısının yüksek olduğu belirlenmiştir $(\mathrm{p}<0.001)$. Preterm yenidoğanların çalışma öncesi ve sonrası BYDDÖ ve YSDF puanları arasındaki fark ortalamalarının kontrol grubuna göre fazla olduğu $(\mathrm{p}=0.001$, $(\mathrm{p}=0.040)$ ve farkın kontrol grubundan kaynaklandığı saptanmıştır $(\mathrm{p}<0.05)$. 
ZOR ve ark.

Aromaterapinin etkinliği

\begin{tabular}{|c|c|c|c|c|c|c|}
\hline $\begin{array}{l}\text { Lafcl }{ }^{55} \\
\text { D./2014 }\end{array}$ & $\begin{array}{l}\text { Aroma Masajının } \\
\text { Yaşlılardaki Kon- } \\
\text { stipasyona Etkisi }\end{array}$ & $\begin{array}{l}\text { Girişim- } \\
\text { kontrol } \\
\text { deseninde } \\
\text { yarı deney- } \\
\text { sel çalışma }\end{array}$ & $\begin{array}{l}48 \text { kişi } \\
\text { Deney Grubu: } 24 \\
\text { Kontrol Gru- } \\
\text { bu: } 24\end{array}$ & $\begin{array}{l}\text { Esansi- } \\
\text { yel Yağ / } \\
\text { biberiye, } \\
\text { zencefil, } \\
\text { karabiber, } \\
\text { badem } \\
\text { yağı/ Masaj }\end{array}$ & $\begin{array}{l}\text { Visual Analog } \\
\text { Skala (VAS), } \\
\text { Günlük Konsti- } \\
\text { pasyon İzlem } \\
\text { Formu }\end{array}$ & $\begin{array}{l}\text { Aroma masajı sırası ve sonrası } \\
\text { girişim grubunda, "dışkılama sayısı" } \\
\text { "dışkı miktarı" ve "dışkı kıvamı" } \\
\text { puan ortalamalarının istatistik- } \\
\text { sel olarak anlamlı düzeyde arttığı, } \\
\text { "dışkılama sırasında ıkınma" ve } \\
\text { "dışkılama sonrası tam boşalamama } \\
\text { hissi" puan ortalamalarının ise azaldığı } \\
\text { belirlenmiştir. Kontrol grubunda ise } \\
\text { "dışkılama sayısı" ve "dışkı miktarı" } \\
\text { puan ortalamalarının arttığı, "dışkılama } \\
\text { sırasında ıkınma" puan ortalamasının ise } \\
\text { azaldığı belirlenmiştir }\end{array}$ \\
\hline $\begin{array}{l}\text { Metin }{ }^{56} \\
\text { G.Z./2015 }\end{array}$ & $\begin{array}{l}\text { Romatoid Artritli } \\
\text { Hastalarda Aro- } \\
\text { materapi Masajı } \\
\text { ve Refleksoloji } \\
\text { Uygulamalarının } \\
\text { Ağrı Ve } \\
\text { Yorgunluğa } \\
\text { Etkileri }\end{array}$ & $\begin{array}{l}\text { Randomize } \\
\text { kontrollü, } \\
\text { yarı deneme } \\
\text { modeli } \\
\text { çalışma }\end{array}$ & $\begin{array}{l}51 \text { kişi } \\
\text { Aromaterapi } \\
\text { masajı grubu:17 } \\
\text { Refleksoloji:17 } \\
\text { Kontrol grubu:17 }\end{array}$ & $\begin{array}{l}\text { Esansi- } \\
\text { yel Yağ / } \\
\text { Lavanta/ } \\
\text { masaj }\end{array}$ & $\begin{array}{l}\text { Visual Analog } \\
\text { Skala (VAS), } \\
\text { Yorgunluk Cid- } \\
\text { diyet Skalası, } \\
\text { Romatoid Artrit } \\
\text { Hastalık Aktivite } \\
\text { Değerlendirme } \\
\text { formu }\end{array}$ & $\begin{array}{l}\text { Aromaterapi grubunda ağrı skorları, } \\
\text { araştırmanın ikinci ve altıncı haftaları } \\
\text { arasında, yorgunluk dördüncü ve altıncı } \\
\text { haftalar arasında azalmıştır ( } p<0,05) \text {. } \\
\text { Refleksoloji grubunda ise ağrı ve yor- } \\
\text { gunluk uygulama boyunca azalmıştır } \\
\text { ( } p<0,05) \text {. Aromaterapi masajı, sabah } \\
\text { tutukluğu üzerine herhangi bir etkide } \\
\text { bulunmamasına rağmen, refleksoloji } \\
\text { sabah tutukluğunu dördüncü haftadan } \\
\text { itibaren kısaltmıştır ( } p<0,05) \text {. Her iki } \\
\text { yöntem de, hastaların sağlık algısını } \\
\text { arttırmıştır }(p<0,05) \text {. }\end{array}$ \\
\hline $\begin{array}{l}\text { Pehlivan }{ }^{57} \\
\text { S./2015 }\end{array}$ & $\begin{array}{l}\text { Diz Osteoartritli } \\
\text { Yaşlı Bireylere } \\
\text { Uygulanan } \\
\text { Aromaterapi } \\
\text { Masajının Ağrı, } \\
\text { Fonksiyonel } \\
\text { Durum Ve Yaşam } \\
\text { Kalitesine Etkisi }\end{array}$ & $\begin{array}{l}\text { Random- } \\
\text { ize ön test } \\
\text { - son test } \\
\text { kontrollü } \\
\text { deneysel } \\
\text { çalışma }\end{array}$ & $\begin{array}{l}\text { Aromaterapi } \\
\text { masaj grubu:30, } \\
\text { Plasebo masaj } \\
\text { grubu: } 30 \\
\text { Kontrol grubu:30 }\end{array}$ & $\begin{array}{l}\text { Esansi- } \\
\text { yel Yağ / } \\
\text { Lavanta/ } \\
\text { Masaj }\end{array}$ & $\begin{array}{l}\text { WOMAC Diz } \\
\text { Osteoartrit } \\
\text { Değerlendirme } \\
\text { Ölçeği, } \\
\text { Alt Bacaklardaki } \\
\text { Artroz ve Yaşam } \\
\text { Kalitesi Ölçeği }\end{array}$ & $\begin{array}{l}\text { Aromaterapi grubunda uygulama } \\
\text { sonrası WOMAC ağrı, tutukluk, günlük } \\
\text { aktivitelerde yaşanan zorluklar anlamlı } \\
\text { olarak azaldığı ve yaşam kalitesi fiziksel } \\
\text { aktivite, ağrı, zihinsel sağlık, sosyal } \\
\text { destek düzeylerinin anlamlı olarak } \\
\text { yükseldiği belirlendi ( } p<0.001 \text { ). Sekiz- } \\
\text { inci hafta değerlendirmesinde sosyal } \\
\text { destek dışındaki tüm parametrelerde } \\
\text { öncesine göre farklılığın anlamlı olarak } \\
\text { devam ettiği saptandı ( }<<0.05 \text { ). Ancak } \\
\text { 4. hafta ile karşılaştırıldığında, 8. hafta } \\
\text { değerlerinde anlamlı olarak bir düşme } \\
\text { saptandı ( } p<0.05 \text { ). Masaj grubunda } \\
\text { uygulama sonrası WOMAC ağrı, } \\
\text { tutukluğun anlamlı olarak azaldığı ve } \\
\text { yaşam kalitesi fiziksel aktivite, ağrı, zi- } \\
\text { hinsel sağlık düzeylerinin anlamlı olarak } \\
\text { yükseldiği belirlendi (p>0.05) }\end{array}$ \\
\hline $\begin{array}{l}\text { Muz }^{58} \\
\text { G./2015 }\end{array}$ & $\begin{array}{l}\text { Hemodiyaliz Te- } \\
\text { davisi Alan Birey- } \\
\text { lerde İnhalasyon } \\
\text { Yoluyla Uygulan- } \\
\text { an Aromaterapinin } \\
\text { Uyku Kalitesi ve } \\
\text { Yorgunluk Düzey- } \\
\text { ine Etkisi }\end{array}$ & $\begin{array}{l}\text { Randomize, } \\
\text { kontrollü, } \\
\text { çalışma }\end{array}$ & $\begin{array}{l}62 \text { kişi } \\
\text { Deney Grubu: } 27 \\
\text { Kontrol Gru- } \\
\text { bu:35 }\end{array}$ & $\begin{array}{l}\text { Esansiyel } \\
\text { Yağ /La- } \\
\text { vanta, Tatlı } \\
\text { portakal/ } \\
\text { İnhaler }\end{array}$ & $\begin{array}{l}\text { Visuel Analog } \\
\text { Skala (VAS) } \\
\text { Pittsburg Uyku } \\
\text { Kalitesi İndeksi } \\
\text { (PUKI) } \\
\text { Piper Yorgunluk } \\
\text { Ölçeği }\end{array}$ & $\begin{array}{l}\text { Müdahale ve kontrol grubundaki bi- } \\
\text { reylerin başlangıç izlemlerinde VAS } \\
\text { yorgunluğu, Piper Yorgunluk Ölçeği ve } \\
\text { PUKİ ölçeği gündüz uyku işlev bozukluğu } \\
\text { alt boyutu hariç diğer tüm alt boyut ve to- } \\
\text { plam puan ortalamalarında almış oldukları } \\
\text { puanlar arasında fark olmadığı (p>0,05), } \\
\text { müdahale grubunun kontrol grubuna göre } \\
\text { diğer izlemlerde VAS yorgunluk, Piper } \\
\text { Yorgunluk Ölçeği ve PUKİ tüm alt boyut } \\
\text { ve toplam puanlarının anlamlı derecede } \\
\text { düştüğü belirlenmiştir( }<<0.05 \text { ) }\end{array}$ \\
\hline
\end{tabular}




\begin{tabular}{|c|c|c|c|c|c|c|}
\hline $\begin{array}{l}\text { Yayla }{ }^{59} \\
\text { M.E./2016 }\end{array}$ & $\begin{array}{l}\text { İnhaler Yolla } \\
\text { Uygulanan } \\
\text { Aromaterapinin } \\
\text { İmplante Edilebilir } \\
\text { Venöz Port Ka- } \\
\text { teter İğne Girişine } \\
\text { Bağlı Prosedürel } \\
\text { Ağrı ve Anksiyete } \\
\text { Üzerine Etkisi }\end{array}$ & $\begin{array}{l}\text { Ran- } \\
\text { domize, } \\
\text { kontrollü, } \\
\text { deneysel } \\
\text { çalışma }\end{array}$ & $\begin{array}{l}123 \text { kişi } \\
\text { lavanta müdahale } \\
\text { grubu: } 41 \text {, okaliptüs } \\
\text { müdahale grubu: } 41 \\
\text { Kontrol grubun: } 41\end{array}$ & $\begin{array}{l}\text { Esansi- } \\
\text { yel Yağ / } \\
\text { Lavanta, } \\
\text { Okliptus/ } \\
\text { Inhaler }\end{array}$ & $\begin{array}{l}\text { Visuel Analog } \\
\text { Skala (VAS) } \\
\text { Durumluk } \\
\text { Kaygı Ölçeği }\end{array}$ & $\begin{array}{l}\text { Araştırma bulguları lavanta müdahale } \\
\text { grubunda kontrol grubuna göre VAS } \\
\text { puan ortalamalarının anlamlı derece- } \\
\text { de düştüğünü göstermiştir ( } p<0,05) \text {. } \\
\text { Okaliptüs müdahale ve kontrol grubun- } \\
\text { daki bireylerin VAS puan ortalamaları } \\
\text { arasında anlamlı bir fark bulunmamışıı } \\
\text { ( }>0,05) \text {. Ayrıca araştırmada lavanta } \\
\text { müdahale, okaliptüs müdahale ve kont- } \\
\text { rol grubundaki bireylerin STAI-I puan } \\
\text { ortalamalarında almış oldukları puanlar } \\
\text { arasında anlamlı bir fark olmadığı bulun- } \\
\text { muştur }(p>0,05) \text {. }\end{array}$ \\
\hline $\begin{array}{l}\text { Uzunçak- } \\
\text { mak }^{60} \text { T./ } \\
2016\end{array}$ & $\begin{array}{l}\text { Üniversite } \\
\text { Öğrencilerine } \\
\text { Uygulanan } \\
\text { Aromaterap- } \\
\text { inin Premenstruel } \\
\text { Sendrom Ile Baş } \\
\text { Etmeye Etkisi }\end{array}$ & $\begin{array}{l}\text { Randomize } \\
\text { kontrollü } \\
\text { deneysel } \\
\text { tasarım } \\
\text { çalışma }\end{array}$ & $\begin{array}{l}77 \text { Kişi } \\
\text { Deney grubu:40 } \\
\text { Kontrol grubu:37 }\end{array}$ & $\begin{array}{l}\text { Esansi- } \\
\text { yel Yağ / } \\
\text { Lavanta/ } \\
\text { İnhaler }\end{array}$ & $\begin{array}{l}\text { Premenstrual } \\
\text { Sendrom } \\
\text { Ölçeği }\end{array}$ & $\begin{array}{l}\text { Araştırmada deney ve kontrol gru- } \\
\text { bunun } 3 \text { izlem süresince PMS ölç̧ği } \\
\text { ortalama puanları karşış̧tıııldığında, } \\
\text { gruplar arasında istatistiksel olarak } \\
\text { anlamlı bir farklılık olduğu belirlen- } \\
\text { miştir ( } p<0.05 \text { ) saptanmıştır. Deney ve } \\
\text { kontrol grupları arasında PMS ölçeği } \\
\text { ve anksiyete, depresif duygulanım, } \\
\text { yorgunluk, sinirlilik, ağrı, şişkinlik, } \\
\text { depresif düš̈ünceler alt boyutları ön } \\
\text { test ve 3. izlem ortalama puanları } \\
\text { açısından istatistiksel olarak anlamlı } \\
\text { bir farklıık olduğu (p<0.05), iştah ve } \\
\text { uyku değişimleri alt boyutlarında } \\
\text { anlamlı bir farklılık olmadığı (p>0.05) } \\
\text { saptanmıştır. }\end{array}$ \\
\hline $\begin{array}{l}\text { Kaymaz }^{61} \mathrm{~T} . \\
\text { T./2016 }\end{array}$ & $\begin{array}{l}\text { Orta Ve lleri } \\
\text { Evre Demans } \\
\text { Hastalarına Uygu- } \\
\text { lanan Aromater- } \\
\text { apinin Ajitasyon } \\
\text { Ve Bakım Verenin } \\
\text { Yüküne Etkisi }\end{array}$ & $\begin{array}{l}\text { Randomize } \\
\text { kontrollü, } \\
\text { araştırma }\end{array}$ & $\begin{array}{l}28 \text { kişi } \\
\text { Müdahale grubu:14 } \\
\text { Kontrol grubu:14 }\end{array}$ & $\begin{array}{l}\text { Esansiyel } \\
\text { Yağ /Lavan- } \\
\text { ta, limon } \\
\text { çimeni/ } \\
\text { İnhaler, } \\
\text { Masaj }\end{array}$ & $\begin{array}{l}\text { Nöropsiki- } \\
\text { yatrik Envant- } \\
\text { er (NPE) } \\
\text { Cohen-Mans- } \\
\text { field Ajitasyon } \\
\text { Envanteri } \\
\text { (CMAE) } \\
\text { Zarit Bakım } \\
\text { Verme Yükü } \\
\text { Ölçeği (ZYBÖ) }\end{array}$ & $\begin{array}{l}\text { Aromaterapi grubunda, CMAE ve NPE } \\
\text { skorları, araştırmanın başlangııına } \\
\text { göre ikinci ve dördüncü haftalarda } \\
\text { azalmıştır ( }<<0,05) \text {. Aromaterapi so- } \\
\text { nunda, müdahale ve kontrol grupları } \\
\text { ZBYÖ skoru arasındaki fark istatistiksel } \\
\text { olarak anlamlı bulunmuştur ( } p<0,05) \text {. } \\
\text { Müdahale grubundaki kişilerin aroma- } \\
\text { terapi uygulama sonrasındaki bakım } \\
\text { yükü, kontrol grubundaki kişilerden } \\
\text { anlamlı derecede daha düşüktür } \\
\text { ( } p<0.05) \text {. }\end{array}$ \\
\hline $\begin{array}{l}\text { Arslan }{ }^{62} \\
\text { D./2016 }\end{array}$ & $\begin{array}{l}\text { Osteoartritli Bi- } \\
\text { reylerde Aroma- } \\
\text { terapi Masajının } \\
\text { Diz Ağrısı Ve } \\
\text { Fonksiyonel Du- } \\
\text { ruma Etkisi }\end{array}$ & $\begin{array}{l}\text { Non- } \\
\text { randomize } \\
\text { girişimsel } \\
\text { çalışma }\end{array}$ & $\begin{array}{l}92 \text { kişi } \\
\text { Aromaterapi masaj } \\
\text { grubu:33, Klasik } \\
\text { masaj grubu: } 30 \\
\text { Kontrol grubu:32 }\end{array}$ & $\begin{array}{l}\text { Esansiyel } \\
\text { Yağ / tatlı } \\
\text { badem } \\
\text { yağı, kayısı } \\
\text { çekirdeği } \\
\text { yağı, } \\
\text { lavanta, } \\
\text { okaliptus, } \\
\text { zencefil } \\
\text { yağı/ Masaj }\end{array}$ & $\begin{array}{l}\text { Vizüel Analog } \\
\text { Skala (VAS), } \\
\text { The Western } \\
\text { Ontario and } \\
\text { McMaster } \\
\text { Üniversi- } \\
\text { tesi (WOMAC) } \\
\text { Osteoartrit } \\
\text { Indeksi }\end{array}$ & $\begin{array}{l}\text { Aromaterapi masajı, klasik masaj ve } \\
\text { kontrol gruplarında bireylerin izlem } \\
\text { haftalarına göre değerlendirilmesinde } \\
\text { ise; tekrarlı ölçümlerde anova kullanıl- } \\
\text { mıştır. Illeri analizinde ise bonfferroni } \\
\text { testinden yararlanılmıştır. Araştırma } \\
\text { kapsamına alınan bireylerin, başlangıç } \\
\text { GKÖ ve WOMAC puan özelliklerine } \\
\text { göre gruplar arasındaki fark istatistiksel } \\
\text { olarak anlamlı olmadığı bulunmuştur } \\
\text { (p }>0,05) \text {. Aromaterapi masaj grubunun } \\
\text { GKÖ (istirahat-aktivite) ve WOMAC in- } \\
\text { deksinden alınan puanları klasik masaj } \\
\text { ve kontrol grubundaki bireylere göre } \\
\text { daha fazla azaldığı ve bu farkın istatik- } \\
\text { sel olarak anlamlı olduğu bulunmuştur } \\
(p<0,001) \text {. }\end{array}$ \\
\hline
\end{tabular}




\begin{tabular}{|c|c|c|c|c|c|}
\hline $\begin{array}{l}\text { Zorba }{ }^{63} \\
\text { P./2016 }\end{array}$ & $\begin{array}{l}\text { Masaj Ve İnhaler } \\
\text { Yollarla Uygulan- } \\
\text { an Aromaterapin- } \\
\text { in Kemoterapiye } \\
\text { Bağlı Akut Bulantı } \\
\text { Kusmaya Etkisinin } \\
\text { Karşılaştırılması }\end{array}$ & $\begin{array}{l}\text { Randomize } \\
\text { kontrollü } \\
\text { araştırma }\end{array}$ & $\begin{array}{l}40 \text { kişi } \\
\text { Aromaterapi } \\
\text { grubu: } 20 \\
\text { Kontrol } \\
\text { grubu: } 20\end{array}$ & $\begin{array}{l}\text { Esansiyel } \\
\text { Yağ / İngiliz } \\
\text { nanesi, } \\
\text { bergamot, } \\
\text { kakule / } \\
\text { İnhaler, } \\
\text { Masaj }\end{array}$ & $\begin{array}{l}\text { Vizüel Analog } \\
\text { Skala (VAS), } \\
\text { Bulantı } \\
\text { Kusma- } \\
\text { Öğürmeye } \\
\text { İlişkin Hasta } \\
\text { Günlüğü } \\
\text { Formu }\end{array}$ \\
\hline
\end{tabular}

Huzurevinde Yaşayan Yaşlılarda Aromaterapi

Yıldırım ${ }^{64}$ Uygulamasının

A.T./2017 Bilişsel Fonksiyonlar Ve Gündüz Uykululuk Durumuna Etkisi

\section{Kontrol} grupsuz ön 15 kişi test-son test Aromaterapi yarı deney- grubu:15 sel çalışma
Blessed

Esansiyel Yağ / Biberiye, limon, lavanta yağ/ İnhaler

\section{Oryantasyon}

Bellek Kon-

santrasyon

Testi,

Epworth

Uykululuk Ölçeği

Aromatik masaj gurubunun 3. ve 4. kemoterapi kürlerinde bulantı-öğürme yaşama durumu inhalasyon ve kontrol grubundakilere göre anlamlı şekilde daha düşüktür $(p<0,001)$. Araştırmamızda, masaj ve inhaler aromaterapi gruplarındaki bireylerde izlenen tüm kürlerde bulantı şiddeti kontrol grubundakilere göre anlamlı derecede azaldığı saptanmıştır ( $p<0.001)$.

İşlem öncesinde katılımcıların ortalama $8,51 \pm 2,33$ olan gündüz uykululuk puanı biberiye-limon yağı karışımı uygulaması sonrası $8,13 \pm 2,54(p>0,05)$, lavanta yağı uygulaması sonrası 5,56 $\pm 4,02(p<0,001)$ bulunmuştur. Gündüz uykululuk puan ortalamasındaki bu anlamlı düşüş lavanta yağının gündüz uykululuk durumunu azalttığını göstermektedir. Uygulama öncesi $14,69 \pm 7,35$ olan bilişsel fonksiyon puan ortalaması biberiye-limon yağı karışımı uygulaması sonrası 11,26 $\pm 7,76(p<0,001)$; lavanta yağı uygulaması sonrası $11,41 \pm 7,78$ $(p<0.001)$ bulunmuştur.

Araştırmada, müdahale grubundaki hastaların 4. ve 6. hafta DN4 ağrı anketi puan ortancası kontrol grubuna göre anlamlı derecede düşük bulunmuş, 6 . haftada kontrol grubunda nöropatik ağrısı olan hasta oranının müdahale grubuna göre anlamlı düzeyde daha yüksek olduğu belirlenmiştir $(p<0,05)$. 2., 4. ve 6. hafta VAS puan ortancası müdahale grubunda kontrol grubuna göre anlamlı düzeyde daha düşük bulunmuştur ( $p>0,05)$.

Çalışma sonunda; örneklemi oluşturan hastaların yaş ortalaması $48.8 \pm 11.35$ olup, $\% 78.8$ i kadındır. Hastaların ağrı puan ortalamaları incelendiğinde; aromaterapi grubunda plasebo ve kontrol grubuna göre işlem ortası ve işlem sonrası anlamlı şekilde azalmakta iken plasebo ve kontrol grubunda artmaktadır $(p<0.05)$.

Miyofasiyal Ağrı Sendromu Olan Bireylerde Tetik Nokta Enjeksiyonu Sırasında

Kasar $^{66}$ S.K./2018 Uygulanan İnhaler Aromaterapinin Ağrı, Anksiyete, Konfor ve Kortizol Düzeyine Etkisi
Visuel Analog Scale-VAS), Durumluk Kaygı Envanteri, Plasebo- Aromaterapi Esansiyel randomize grubu:22 Yağ/Lakontrollü plasebogru- vanta/ çalışma bu: 22 kontrol Inhaler grubu:22
Genel Konfor

Ölçeği,

Hasta ve

Hekim

Memnuniyet

Skalası
Hastaların anksiyete düzeyleri incelendiğinde, aromaterapi grubundaki hastaların işlem sonrası ölçüm medyanının, işlem öncesi ölçüm medyanından anlamlı olarak düşük olduğu ( $p>0.05$ ). Ayrıca aromaterapi grubundaki bireylerin distress termometresi işlem sonrası ölçüm medyan değeri anlamlı olarak düşerken, plasebo ve kontrol grubundaki bireylerin anlamlı olarak artmaktadır. Aromaterapi, plasebo ve kontrol gruplarında genel konfor ölçeği işlem öncesi ve sonrası ölçüm ortalamaları karşılaştırıldığında aromaterapi grubunda işlem sonrası toplam ortalaması anlamlı olarak yüksek iken plasebo ve kontrol gruplarında anlamlı derece düşüktür $(p<0,05)$. 


\begin{tabular}{|c|c|c|c|c|c|c|}
\hline $\begin{array}{l}\text { Ertürk }{ }^{67} \\
\text { E.N./2019 }\end{array}$ & $\begin{array}{l}\text { Kemoterapi Alan } \\
\text { Hastalara Uygula- } \\
\text { nan Nane Yağının } \\
\text { Bulantı Kusma ve } \\
\text { Öğürme Üzerine } \\
\text { Etkisi }\end{array}$ & $\begin{array}{l}\text { Kalitatif } \\
\text { (bireysel de- } \\
\text { rinlemesine } \\
\text { görüşme) } \\
\text { ve kantitatif } \\
\text { (randomize } \\
\text { kontrollü) } \\
\text { çalışma }\end{array}$ & $\begin{array}{l}80 \text { kişi } \\
\text { müdahale grubu:36 } \\
\text { kontrol grubu: } 44\end{array}$ & $\begin{array}{l}\text { Esansiyel } \\
\text { Yağ / Nane, } \\
\text { Tatlı badem } \\
\text { yağı / } \\
\text { İnhaler }\end{array}$ & $\begin{array}{l}\text { Visüel Analog } \\
\text { Skala (VAS) } \\
\text { Rhodes } \\
\text { Bulantı, Kusma } \\
\text { ve Öğürme } \\
\text { Indeksi }\end{array}$ & $\begin{array}{l}\text { Müdahale grubundaki bireylerin kont- } \\
\text { rol grubundaki bireylere göre nane } \\
\text { yağı uygulaması sonrası bulantı şidde- } \\
\text { ti, bulantı, kusma ve öğürme semp- } \\
\text { tomlarında anlamlı derecede }(p<0.05) \\
\text { azalma olduğu ve daha az antiemetik } \\
\text { ilaç kullandıkları belirlenmiştir. }\end{array}$ \\
\hline $\begin{array}{l}\text { Işık } 68 \\
\text { A.I./2019 }\end{array}$ & $\begin{array}{l}\text { Üniversite } \\
\text { Öğrencilerinin } \\
\text { Sigara İçme } \\
\text { Alışkanlıkları } \\
\text { Üzerinde Aroma- } \\
\text { terapinin Etkisi }\end{array}$ & $\begin{array}{l}\text { Kontrol } \\
\text { gruplu, yarı } \\
\text { deneysel } \\
\text { araştırma }\end{array}$ & $\begin{array}{l}58 \text { kişi } \\
\text { Karabiber grubu: } 11 \\
\text { melekotu grubu:18 } \\
\text { Kontrol grubu:19 }\end{array}$ & $\begin{array}{l}\text { Esansiyel } \\
\text { Yağ /Kara- } \\
\text { biber, me- } \\
\text { lekotu yağı } \\
\text { / İnhaler }\end{array}$ & $\begin{array}{l}\text { Fagerström } \\
\text { Nikotin } \\
\text { Bağımlılığı Testi }\end{array}$ & $\begin{array}{l}\text { Araştırmadan elde edilen bulgulara } \\
\text { göre, grup içi karşılaştırmada karabiber } \\
\text { ve melekotu yağı uygulayan öğren- } \\
\text { cilerin uygulama sonrası sigara içme } \\
\text { isteği puan ortalamaları azalmıştır. } \\
\text { Kontrol grubunda anlamlı bir değişiklik } \\
\text { olmamıştır. Gruplararası karşılaştırmada } \\
\text { deney grubunda (karabiber ve meleko- } \\
\text { tu yağı) yer alan öğrencilerin uygulama } \\
\text { sonrası sigara içme isteğinde azalma } \\
\text { olduğu tespit edilmiştir. }\end{array}$ \\
\hline $\begin{array}{l}\text { Şimşek }{ }^{69} \\
\text { P./2019 }\end{array}$ & $\begin{array}{l}\text { Lavanta Yağı } \\
\text { Aromaterapisinin } \\
\text { Acil Servis Sağlık } \\
\text { Çalışanlarında } \\
\text { Kalabalıklaşmayla } \\
\text { illişkili Anksiyete } \\
\text { Düzeyi Üzerin- } \\
\text { deki Etkisinin } \\
\text { Değerlendirilmesi }\end{array}$ & $\begin{array}{l}\text { Girişimsel } \\
\text { çalışma }\end{array}$ & $\begin{array}{l}35 \text { kişi } \\
\text { Girişim grubu:35 }\end{array}$ & $\begin{array}{l}\text { Esansiyel } \\
\text { Yağ/Lavan- } \\
\text { ta/ İnhaler }\end{array}$ & $\begin{array}{l}\text { Durumluk } \\
\text { Anksiyete } \\
\text { Ölçeği, } \\
\text { Ulusal Acil } \\
\text { Servisler } \\
\text { Kalabalıklaşma } \\
\text { Çalışması ölçeği }\end{array}$ & $\begin{array}{l}\text { Aromaterapi öncesinde ve sonrasında } \\
\text { acil servis sağlık çalışanlarının anksiye- } \\
\text { te düzeyi Durumluk Anksiyete Ölçeği } \\
\text { kullanılarak değerlendirildi. Durumluk } \\
\text { anksiyete düzeyi ile kalabalıklaşma } \\
\text { arasında pozitif yönde orta düzeyde } \\
\text { anlamlı bir ilişki olduğu belirlendi } \\
\text { ( } r=0.415, p<0.001) \text {. Lavanta yağı } \\
\text { aromaterapisinin acil servis sağlık } \\
\text { çalışanlarında kalabalıklaşma ile ilişkili } \\
\text { anksiyete düzeyinin azaltılmasında } \\
\text { istatistiksel olarak anlamlı bir etkiye } \\
\text { sahip olduğu saptandı ( } p<0.05 \text { ). }\end{array}$ \\
\hline $\begin{array}{l}\text { Karaaslan }^{70} \\
\text { M.M./2020 }\end{array}$ & $\begin{array}{l}\text { Bebeklere Uygula- } \\
\text { nan Aromaterapi } \\
\text { ve Abdominal } \\
\text { Masajın Kon- } \\
\text { stipasyon ve } \\
\text { Annenin Kaygı } \\
\text { Düzeyine Etkisi }\end{array}$ & $\begin{array}{l}\text { Yarı } \\
\text { Deneysel } \\
\text { Çalışma }\end{array}$ & $\begin{array}{l}69 \text { bebek } \\
\text { Aromaterapi masaj } \\
\text { grubu, } 23 \\
\text { klasik masaj grubu: } \\
23 \text { kontrol grubu: } 23\end{array}$ & $\begin{array}{l}\text { Esansiyel } \\
\text { Yağ / La- } \\
\text { vanta, tatlı } \\
\text { badem / } \\
\text { Masaj }\end{array}$ & $\begin{array}{l}\text { Durumluk } \\
\text { Kaygı Envanteri }\end{array}$ & $\begin{array}{l}\text { Aromaterapi masaj grubu ve klasik } \\
\text { masaj grubunda bebeğin kaka mik- } \\
\text { tarı, bebeğin kaka yaparken ağlama } \\
\text { durumu ve bebeğin gaz çıartma } \\
\text { durumunun istatistiksel olarak anlamlı } \\
\text { olduğu, aromaterapi masaj grubunda } \\
\text { etkinin daha fazla olduğu saptandı } \\
\text { ( } p<0.05 \text { ). Aromaterapi masaj uygula- } \\
\text { nan gruptaki annelerin, diğer grup- } \\
\text { lardaki annelere göre daha düşük } \\
\text { kaygı ortalama değerine sahip olduğu } \\
\text { saptandı. En düşük durumluluk kaygı } \\
\text { envanteri ortalama değeri masajdan } \\
4 \text { hafta sonra aromaterapi grubunda } \\
\text { elde edildi ( } p<0.05 \text { ). }\end{array}$ \\
\hline
\end{tabular}


ürünlerin farmakolojik ajanlara oranla daha uygun ve güvenilir alternatifler olarak kabul edilmesine ve kullanımının artmasına neden olmaktadır [2, 25,26]. Aromaterapinin bu şekilde yaygın kullanımından dolayı, sağlık hizmetlerinin her basamağında görev alan hemşireler tarafından aromaterapi ile ilgili çalışmaların yürütülmesi ihtiyacı doğmuştur. Ülkemizde konu ile ilgili yürütülen tezlere bakıldığında ilk uygulamaların 2007 yılında Çocuk Sağlığı ve Hastalıkları Hemşireliği ve Cerrahi Hastalıkları Hemşireliği anabilim dallarında doktora tezi olarak yürütüldüğü görülmektedir (Tablo 1). Bu konudaki çalışmaların son on yılda arttığı da dikkati çekmektedir. Yürütülen tezlere bakıldığında, 20'sinin yüksek lisans 24'ünün doktora tezi olduğu ve çoğunluğunun İç Hastalıkları Hemşireliği Anabilim Dalında yürütüldüğü saptanmıştır. Bunun yanı sıra hemşireliğin tüm anabilim dallarında da aromaterapi ile ilgili çalışmalar yürütülmüştür (Tablo 1). Aromaterapide kullanılan uçucu yağların bireyler üzerinde fiziksel, psikolojik ve ruhsal olarak birçok etkisi mevcuttur $[2,25]$. Aromatik yağlar etkilerini sinir sistemine veya kan dolaşımına katılarak bütün vücut sistemleri üzerinde gösterebilirler. Bu etkilere baktığımızda, analjezik etki, antienflamatuvar etki, duyusal öğrenme, bilinçli algılama ve zedelenmiş dokunun onarımında kullanılan uçucu yağların, bitkilerin kendisinden 100 kat daha yoğun etkiye sahiptir [26, 71]. Aromaterapik uygulamalar hastalığın yalnızca tedavisinde etkili olmayıp aynı zamanda vücut ve ruh sağlığı için geniş kapsamlı bir etkileşim üzerinden tedavi öngören uygulamalardır. Bu bilgiler ışığında aromaterapinin etkisini inceleyen tezlerin 25 'inde aromaterapinin kaygı/anksiyete/stres üzerine, 23'ünde uyku ve 19'unda ise ağrı üzerindeki etkisi incelenmiş ve hissedilen ağrı ve kaygı/anksiyete düzeyini, bulantı- kusma ve öğürmeyi, yorgunluk düzeyi ve şiddetini, ajitasyonu ve bakım verenlerinin bakım yükünü, premenstrual semptomları, konstipasyon şikayetlerini, bebeklerde koliği azalttığı uyku kalitesini, yaşam kalitesini, konfor düzeyini, memnuniyet düzeyini arttırdığı ve fiziksel fonksiyonları, yaşamsal bulguları olumlu yönde etkilediği görülmüştür (Tablo 2, Tablo 3). Ayrıca aromaterapinin etkisinin incelendiği sayısız çalışma, güvenlik sınırları içerisinde yapılan aromaterapi uygulamalarının ne kadar yararlı olabileceği gerçeğini kanıtlanmıştır. Aromaterapinin kullanımı ile hemşirelik bakımının kalitesini artacağı ve hemşire ile hastası arasında güvenli bir ilişki sağlayarak tedavi edici yönü ile beraber hemşire ile hasta arasında güçlü bir terapötik etkisi olduğu düşünülmektedir.

Sonuç olarak, hemşirelik alanında aromaterapinin etkisinin incelendiği pek çok çalışma bulunmaktadır. Ancak buna rağmen hemşireliğin tüm anabilim dallarında kullanımının sağlanması için daha fazla çalışmaya ihtiyaç duyulmakta ve bu alanda çalışacak hemşirelere verilecek eğitimlerle kontrollü uygulamaları artırılması önerilmektedir.

\section{Çıkar çatışması/finansal destek beyanı}

Bu yazıdaki hiçbir yazarın herhangi bir çıkar çatışması yoktur. Yazının herhangi bir finansal desteği yoktur.

\section{KAYNAKLAR}

1. Gültekin E. Ethical ıssues in aromatherapy courses in Turkey, Turkiye Klin. J. Med. Ethics-Law Hist. 2020; 28: 273-278.

2. Kanat T. Aromaterapi. Journal of Biotechnology and Strategic Health Research, 2019; 3: 67-73.

3. Barış EN, Öztunç G. Sağlık çalışanlarında aromaterapı冈nı冈n stres ve anksı囚yete üzerı冈ne etkı冈sı冈. 2016; 5: 107-11.

4. Farahani MA, Afsargharehbagh R., Marandi F, Moradi M, Hashemi SM, Moghadam MP, Balouchi A. Effect of aromatherapy on cancer complications: A systematic review. Complementary therapies in medicine, 2019; 47: 102169.

5. Tanvisut R, Traisrisilp K. And Tongsong T. Efficacy of aromatherapy for reducing pain during labor: a randomized controlled trial, Arch. Gynecol. Obstet. 2018; 297: 1145-50.

6. Lai et al. Effectiveness of aroma massage on advanced cancer patients with constipation: A pilot study, Complement. Ther. Clin. Pract. 2011; 17: 37-43.

7. Scuteri D. et al. Aromatherapy and aromatic plants for the treatment of behavioural and psychological symptoms of dementia in patients with alzheimer's disease: clinical evidence and possible mechanisms, Evidence-based Complement. Altern. Med. 2017.

8. Nikjou R, Kazemzadeh R, Asadzadeh F, Fathi R. And Mostafazadeh $F$. The effect of lavender aromatherapy on the symptoms of menopause, J. Natl. Med. Assoc., 2018; 110: 265-69.

9. Olapour A, Behaeen K, Akhondzadeh R, Soltani F, Razavi FAS, Bekhradi R. The effect of inhalation of aromatherapy blend containing lavender essential oil on cesarean postoperative pain, Anesthesiol. Pain Med., 2013; 3: 203-7.

10. Mansour Lamadah $\mathrm{S}$. The effect of aromatherapy massage using lavender oil on the level of pain and anxiety during labour among primigravida women, Am. J. Nurs. Sci. 2016; 5: 37-41.

11. Uzunçakmak, T. Ayaz Alkaya S., Effect of aromatherapy on coping with premenstrual syndrome: A randomized controlled trial, Complement. Ther. Med., 2017; 36: 63-7.

12. Apay SE., Arslan S, Akpinar RB, Celebioglu A. Effect of Aromatherapy Massage on Dysmenorrhea in Turkish Students, Pain Manag. Nurs., 2012; I: 236-40.

13. Çetinkaya B, Başbakkal Z. The effectiveness of aromatherapy massage using lavender oil as a treatment for infantile colic Int. J. Nurs. Pract., 2012; 18: 164-69.

14. Nategh M, Heidari MR, Ebadi A, Kazemnejad A, Beigi MAB, Effect of lavender aromatherapy on hemodynamic indices among patients with acute coronary syndrome: a randomized clinical trial, Iran J. Crit. Care Nurs. 2015; 7: 201-8.

15. Taavoni, S., Darsareh, F., Joolaee, S. And Haghani, H. The effect of aromatherapy massage on the psychological symptoms of postmenopausal Iranian women, Complement. Ther. Med. 2013; 21: 158-63. 
16. Pehlivan S, Karadakovan A. Effects of aromatherapy massage on pain, functional state, and quality of life in an elderly individual with knee osteoarthritis, Japan J. Nurs. Sci. 2019; 16: 450-8.

17. Efe Arslan,D, Kutlutürkan $S$, Korkmaz M. The effect of aromatherapy massage on knee pain and functional status in participants with osteoarthritis, Pain Manag. Nurs., 2019; 20: 62-9.

18. Demirbağ BC, Erc B. The effects of sleep and touch therapy on symptoms of fibromyalgia and depression. Iranian journal of public health, 2012; 41: 44 .

19. Vaziri,F, Khosropoor M, Hidari M, Pourahmad S, Morshed Behbahani B, Saki F. The effect of aromatherapy by lavender oil on Infant vaccination pain: a double blind randomized controlled trial, J. Caring Sci. 2019; 8: 17-21.

20. Joulaeerad N, Ozgoli G, Hajimehdipoor H, Ghasem E, and Salehimoghaddam F. Effect of aromatherapy with peppermint oil on the severity of nausea and vomiting in pregnancy: A single-blind, randomized, placebo-controlled trial, J. Reprod. Infertil., 2018; 19:32-8.

21. Farahani MA. Et al., Effect of aromatherapy on cancer complications: A systematic review, Complement. Ther. Med. 2019; 47: 102169.

22. Genç F, Karada区 S, Kiliç AN, Tan M, Cerit D. The effect of aromatherapy on sleep quality and fatigue level of the elderly: A randomized controlled study, Holist. Nurs. Pract. 2020; 34: 155-62

23. Barati F, Nasiri A, Akbari N, Sharifzadeh G. The effect of aromatherapy on anxiety in patients, Nephrourol. Mon., 2016; 8.

24. Rezaie-Keikhaie K.et al. Effect of aromatherapy on post-partum complications: A systematic review, Complement. Ther. Clin. Pract., 2019; 35: 290-95.

25. Rajai,N, Sajadi SA, Teymouri,F, Zareiyan A, Siavoshi S, Malmir M. The effect of aromatherapy with lavender essential oil on anxiety and stress in patients undergoing coronary artery bypass graft surgery, Jundishapur J. Chronic Dis. Care, 2016; 5.

26. Özdemir H, Öztunç G. Hemşirelik uygulamalarında aromaterapi. Turkiye Klinikleri Hemsirelik Bilimleri, 2013; 5.

27. Yaman S. (2011),Lavanta yağıyla uygulanan sırt masajının yaşılırın uyku kalitesine etkisinin incelenmesi, Yüksek Lisans Tezi, Fırat Üniversitesi, Sağlık Bilimleri Enstitiüsü, Elazığ.

28. Karabulut H. (2014), Doğum eyleminde aromaterapinin etkileri, Yüksek Lisans Tezi, İstanbul Üniversitesi, Sağlık Bilimleri Enstitüsü, Kadın Sağlığı ve Hastalıkları Hemşireliği, İstanbul.

29. Şentürk A. (2015), Hemodiyaliz hastalarına inhalasyon yolu ile lavanta yağı uygulamasının anksiyete düzeyi ve uyku kalitesine etkisi, Yüksek Lisans Tezi, Erciyes Üniversitesi, Sağlık Bilimleri Enstitüsü, Kayseri.

30. Barış N. (2015), Aromaterapinin yoğun bakım ünitesinde çalışan hemşirelerin stres ve anksiyeteleri üzerine etkisi, Yüksek Lisans Tezi, Çukurova Üniversitesi, Sağlık Bilimleri Enstitüsü, Adana.
31. IIlter M.S. (2016) Onkoloji hastalarına port kateterizasyonu işlemi sırasında uygulanan inhaler aromaterapinin ağrıya etkisi, Yüksek Lisans Tezi, Gaziantep Üniversitesi, Sağlık Bilimleri Enstitüsü, Gaziantep.

32. Ayik C. (2016) Ameliyat öncesi dönemde aromaterapi masajının anksiyete ve uyku kalitesine etkisinin incelenmesi, Yüksek Lisans Tezi, Dokuz Eylül Üniversitesi, Sağlık Bilimleri Enstitüsü, İzmir.

33. Gürakan G. (2016), Palyatif bakım alan kanser hastalarında aromaterapi sırt masajının ağrı şiddeti ve plazma beta endorfin düzeyine etkisi, Yüksek Lisans Tezi, Ege Üniversitesi, Sağlık Bilimleri Enstitüsü, İzmir.

34. Dalkıran S.S (2017), Preoperatif dönemdeki kanser hastalarında lavanta yağı ile yapılan sırt masajının uykuya etkisi, Yüksek Lisans Tezi, Marmara Üniversitesi, Sağlık Bilimleri Enstitüsü, İstanbul.

35. Gürler M. (2017), Menopozal dönemdeki kadınlara uygulanan aromaterapinin uyku ve yaşam kalitesine etkisi, Yüksek Lisans Tezi, Nevşehir Hacı Bektaş Veli Üniversitesi, Fen Bilimleri Enstitüsü, Nevşehir.

36. Cenkci Z. (2017), Aromaterapinin doğum eylemindeki ağrı, konfor ve memnuniyet üzerine etkisi, Yüksek Lisans Tezi, Çukurova Üniversitesi, Sağlık Bilimleri Enstitüsü, Adana.

37. Beyliklioğlu A. (2017), Aromaterapinin mastektomi öncesi hastaların anksiyeteleri üzerine etkisi, Yüksek Lisans Tezi, Çukurova Üniversitesi, Sağlık Bilimleri Enstitüsü, Adana.

38. Genç H. (2017), Lavanta yağının benign prostat hiperplazili hastaların ameliyat öncesi yaşam bulguları ve kaygı düzeyine etkisi, Yüksek Lisans Tezi, İnönü Üniversitesi, Sağlık Bilimleri Enstitüsü, Malatya.

39. Taşan E. (2018), İnhaler lavantanın hemodiyaliz hastalarında damara ulaşım sırasında oluşan ağrıya etkisi, Yüksek Lisans Tezi, Gaziantep Üniversitesi, Sağlık Bilimleri Enstitüsü, Gaziantep.

40. Gülşen G. (2018), Üst gastrointestinal endoskopi işlemi uygulanan hastalara müzik eşliğinde uygulanan inhaler aromaterapinin vital bulgulara etkisi, Yüksek Lisans Tezi, Gaziantep Üniversitesi, Sağlık Bilimleri Enstitüsü, Gaziantep.

41. Sert C. (2019), Diz osteoartriti olan hastalarda, Isırgan-zencefil esansiyel yağlarıyla yapılan masajın ve buz uygulamasının ağrı üzerine etkinliğinin değerlendirilmesi, Yüksek Lisans Tezi, Düzce Üniversitesi, Sağlık Bilimleri Enstitüsü, Düzce.

42. Özdemir T.S. (2019), Hemodiyaliz hastalarında av fistül uygulaması sırasında oluşan ağrıyı gidermede lavanta aromaterapinin etkisi, Yüksek Lisans Tezi, Ege Üniversitesi, Sağlık Bilimleri Enstitüsü, İzmir.

43. Koç E. (2019), Lavanta yağının kronik otitis media hastalarının ameliyat öncesi yaşam bulguları ve kaygı düzeyine etkisi, Yüksek Lisans Tezi, İnönü Üniversitesi, Sağlık Bilimleri Enstitüsü, Malatya.

44. Coşar B.F. (2019), Aromaterapi masajının kronik nonmalign ağrısı olan hastalarda ağrı, anksiyete ve uyku kalitesi üzerine etkisinin incelenmesi, Yüksek Lisans Tezi, Ege Üniversitesi, Sağlık Bilimleri Enstitüsü, İzmir.

45. Öz M. (2019), Yaşlılarda aromaterapi masajının uyku kalitesi ve uykululuk düzeyine etkisi, Yüksek Lisans Tezi, Üsküdar Üniversitesi, Sağlık Bilimleri Enstitüsü, İstanbul. 
46. Sezgin Y. (2020), Arterio-venöz fistül kanülasyonu öncesi uygulanan aromaterapi ve el masajının ağrı ve stres düzeylerine etkisi, Yüksek Lisans Tezi, Düzce Üniversitesi, Sağlık Bilimleri Enstitüsü, Düzce.

47. Çetinkaya B. (2007), Aromaterapi masajının bebeklerde koliğin giderilmesi üzerine etkisinin incelenmesi, Doktora Tezi, Ege Üniversitesi, Sağlık Bilimleri Enstitüsü, İzmir.

48. Arslan S. (2007), Dokunma, müzikterapi ve aromaterapinin yoğun bakım hastalarının fizyolojik durumlarına etkisi, Doktora Tezi, Atatürk Üniversitesi, Sağlık Bilimleri Enstitüsü, Erzurum.

49. Demirbağ C. B. (2011), Müzik ve aromaterapi eşliğinde yapılan uyku ve dokunmanın fibromiyalji hastalarında fibromiyaljinin etki düzeyi ile yorgunluk ve uyku kalitesine etkisi, Doktora Tezi, Atatürk Üniversitesi, Sağlık Bilimleri Enstitüsü, Erzurum.

50. Ovayolu Ö. (2011), Kemoterapi alan meme kanserli kadınlara uygulanan aromaterapinin semptomlara ve yaşam kalitesi etkisi, Doktora Tezi, Erciyes Üniversitesi, Sağlık Bilimleri Enstitüsü, Kayseri.

51. Cürcani M. (2012), Hemodiyaliz hastalarına uygulanan aromaterapinin kaşıntı üzerine etkisi, Doktora Tezi, Atatürk Üniversitesi, Sağlık Bilimleri Enstitüsü, Erzurum.

52. Taşdemir N. (2012), Gevşeme tekniği, aromaterapi ve her iki yöntemin birlikte uygulanmasının ameliyat sonrası ağrıya etkisi, Doktora Tezi, Ege Üniversitesi, Sağlık Bilimleri Enstitüsü, İzmir.

53. Özdemir H. (2012), Esansiyel hipertansiyonlu kadınlara inhalasyon yoluyla uygulanan aromaterapinin arteriyel kan basıncl, nabız ve kaygı düzeyine etkisi, Doktora Tezi, Erciyes Üniversitesi, Sağlık Bilimleri Enstitüsü, Kayseri.

54. Tosun Ö. (2013), Aromaterapi, müzikterapi ve vibrasyon uygulamalarının yenidoğanın stres ve davranışları üzerine etkisi, Doktora Tezi, Erciyes Üniversitesi, Sağlık Bilimleri Enstitüsü, Kayseri.

55. Lafcı D. (2014), Aroma masajının yaşlılardaki konstipasyona etkisi, Doktora Tezi, Atatürk Üniversitesi, Sağlık Bilimleri Enstitüsü, Erzurum.

56. Metin G.Z. (2015), Romatoid artritli hastalarda aromaterapi masajı ve refleksoloji uygulamalarının ağrı ve yorgunluğa etkileri, Doktora Tezi, Hacettepe Üniversitesi, Sağlık Bilimleri Enstitüsü, Ankara.

57. Pehlivan S. (2015), Diz osteoartritli yaşlı bireylere uygulanan aromaterapi masajının ağıı, fonksiyonel durum ve yaşam kalitesine etkisi, Doktora Tezi, Ege Üniversitesi, Sağlık Bilimleri Enstitüsü, İzmir.

58. Muz G. (2015), Hemodiyaliz tedavisi alan bireylerde inhalasyon yoluyla uygulanan aromaterapinin uyku kalitesi ve yorgunluk düzeyine etkisi, Doktora Tezi, Erciyes Üniversitesi, Sağlık Bilimleri Enstitüsü, Kayseri.

59. Yayla M.E. (2016), İnhaler yolla uygulanan aromaterapinin implante edilebilir venöz port kateter iğne girişine bağlı prosedürel ağrı ve anksiyete üzerine etkisi, Doktora Tezi, Hacettepe Üniversitesi, Sağlık Bilimleri Enstitüsü, Ankara.
60. Uzunçakmak T. (2016), Üniversite öğrencilerine uygulanan aromaterapinin premenstruel sendrom ile baş etmeye etkisi, Doktora Tezi, Gazi Üniversitesi, Sağlık Bilimleri Enstitüsü, Ankara.

61. Kaymaz T. T. (2016), Orta ve ileri evre demans hastalarına uygulanan aromaterapinin ajitasyon ve bakım verenin yüküne etkisi, Doktora Tezi, Hacettepe Üniversitesi, Sağlık Bilimleri Enstitüsü, Ankara.

62. Arslan D. (2016), Osteoartritli bireylerde aromaterapi masajının diz ağrısı ve fonksiyonel duruma etkisi, Doktora Tezi, Gazi Üniversitesi, Sağlık Bilimleri Enstitüsü, Ankara.

63. Zorba P. (2016), Masaj ve inhaler yollarla uygulanan aromaterapinin kemoterapiye bağlı akut bulantı kusmaya etkisinin karşılaştırılması, Doktora Tezi, Hacettepe Üniversitesi, Sağlık Bilimleri Enstitüsü, Ankara

64. Yıldırım A.T. (2017), Huzurevinde yaşayan yaşılıarda aromaterapi uygulamasının bilişsel fonksiyonlar ve gündüz uykululuk durumuna etkisi, Doktora Tezi, Gazi Üniversitesi, Sağlık Bilimleri Enstitüsü, Ankara.

65. İzgü N. (2017), El ve ayağa uygulanan aromaterapi masajının kemoterapi ilişkili periferal nöropatik ağrı ve yorgunluk üzerine etkisi, Doktora Tezi, Hacettepe Üniversitesi, Sağlık Bilimleri Enstitüsü, Ankara.

66. Kasar S.K.(2018), Miyofasiyal Ağrı sendromu olan bireylerde tetik nokta enjeksiyonu sırasında uygulanan inhaler aromaterapinin ağrı, anksiyete, konfor ve kortizol düzeyine etkisi, Doktora Tezi, Ege Üniversitesi, Sağlık Bilimleri Enstitüsü, İzmir.

67. Ertürk E.N. (2019), Kemoterapi alan hastalara uygulanan nane yağının bulantı kusma ve öğürme üzerine etkisi, Doktora Tezi, Erciyes Üniversitesi, Sağlık Bilimleri Enstitüsü, Kayseri.

68. Iş̧ı A.ı. (2019), Üniversite Öğrencilerinin Sigara İçme Alışkanlıkları Üzerinde Aromaterapinin Etkisi, Doktora Tezi, İstanbul Üniversitesi-Cerrahpaşa, Lisansüstü Eğitim Enstitüsü, İstanbul.

69. Şimşek P. (2019), Lavanta yağı aromaterapisinin acil servis sağlık çalışanlarında kalabalıklaşmayla ilişkili anksiyete düzeyi üzerindeki etkisinin değerlendirilmesi, Doktora Tezi, İstanbul Karadeniz Teknik Üniversitesi, Sağlık Bilimleri Enstitüsü, Trabzon.

70. Karaaslan M.M. (2020), Bebeklere uygulanan aromaterapi ve abdominal masajın konstipasyon ve annenin kaygı düzeyine etkisi, Doktora Tezi, Atatürk Üniversitesi, Sağlık Bilimleri Enstitüsü, Erzurum.

71. Watt G., and Janca, A. Aromatherapy in nursing and mental health care, Contemp. Nurse, 2008;30:(1), 69-75, , doi: 10.5172/ conu.673.30.1.69. 